\title{
Data report: consolidation characteristics of sediments from Sites C0002, C0006, and C0007, IODP Expeditions 315 and 316, NanTroSEIZE Stage 1'
}

\author{
Junhua Guo, ${ }^{2}$ William J. Likos, ${ }^{3}$ Michael B. Underwood, ${ }^{2}$ Robert M. Skarbek, ${ }^{4}$
}

Nick Adamson, ${ }^{4}$ and Demian Saffer ${ }^{4}$

\section{Chapter contents}

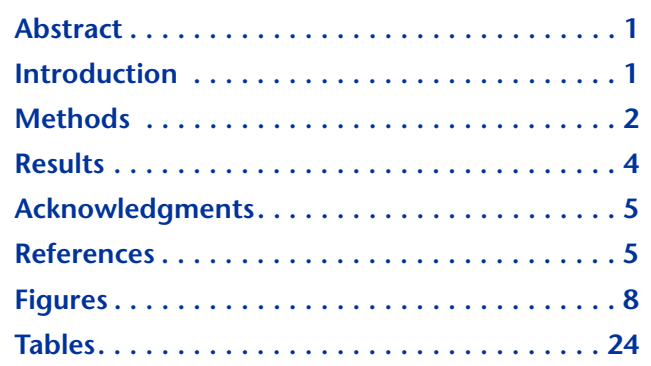

'Guo, J., Likos, W.J., Underwood, M.B., Skarbek, R.M., Adamson, N., and Saffer, D., 2011. Data report: consolidation characteristics of sediments from Sites C0002, C0006, and C0007, IODP Expeditions 315 and 316, NanTroSEIZE Stage 1. In Kinoshita, M., Tobin, H., Ashi, J., Kimura, G., Lallemant, S., Screaton, E.J., Curewitz, D., Masago, H., Moe, K.T., and the Expedition 314/315/316 Scientists, Proc. IODP, 314/315/316: Washington, DC (Integrated Ocean Drilling Program Management International, Inc.). doi:10.2204/iodp.proc.314315316.213.2011 ${ }^{2}$ Department of Geological Sciences, 101 Geology building, University of Missouri, Columbia MO 65211, USA. Correspondence author: jg2kc@mail.missouri.edu

${ }^{3}$ Department of Civil and Environmental Engineering, University of Missouri, Columbia MO 65211, USA.

${ }^{4}$ Rock and Sediment Mechanics Laboratory, The Pennsylvania State University, University Park PA 16802, USA.

\section{Abstract}

Eighteen constant-rate-of-strain consolidation tests were performed on whole-round core samples from Integrated Ocean Drilling Program Sites C0002, C0006, and C0007. These sites are located along the Kumano transect of the Nankai Trough offshore south-central Japan; Site C0002 is in the forearc basin and the other two are in the frontal thrust zone. Sample depths range from $\sim 35$ to $920 \mathrm{~m}$ core depth below seafloor. The objectives of the laboratory tests were to obtain the compression characteristics of the sediments, to estimate the maximum pretest consolidation stress $\left(P_{c}^{\prime}\right)$, and to determine values of hydraulic conductivity $(K)$, intrinsic permeability $(k)$, and compression index $\left(\mathrm{C}_{c}\right)$. Values of $\mathrm{C}_{\mathrm{c}}$ at Site C0002 range from 0.391 to 0.780 (average $=0.584$ ); comparable values are 0.236 to 0.418 (average $=0.302$ ) in the trench-wedge facies at Sites C0006 and C0007. Values of in situ intrinsic permeability $\left(k_{\mathrm{i}}\right)$ at Site $\mathrm{C} 0002$ show no trend with depth, ranging from $2.67 \times 10^{-17} \mathrm{~m}^{2}$ to $2.56 \times 10^{-18} \mathrm{~m}^{2}$. Estimates of $k_{\mathrm{i}}$ at Sites C0006 and C0007 decrease with depth and range from $1.85 \times 10^{-16} \mathrm{~m}^{2}$ to $6.08 \times 10^{-18} \mathrm{~m}^{2}$. Test-derived values of $P^{\prime}{ }_{\mathrm{c}}$ are consistently greater than the estimates of in situ hydrostatic vertical effective stress at equivalent sample depths, which means the specimens are overconsolidated. Environmental scanning electron microscopy was used to assess the degree of preferred particle orientation of the microfabric. The index of orientation averages 0.33 at Sites C0006 and C0007 and 0.38 at Site C0002. Most vertical sections show indexes of orientation greater than those for horizontal sections; exceptions to this pattern include several samples from Sites $\mathrm{C0006}$ and $\mathrm{C0007}$ where bedding dips $>40^{\circ}$. Samples from deeper intervals of the forearc basin (Site C0002) and from the accreted upper Shikoku Basin facies at Site C0007 yielded the highest values of orientation index $(>0.40)$, indicating better alignment of platy grains.

\section{Introduction}

Consolidation characteristics of marine sediments and sedimentary rock are used to evaluate diagenetic, hydrologic, and compaction processes during subduction and accretion (e.g., Lee et al., 1973; Trabant et al., 1975; Carson, 1977; Shepard and Bryant, 1977; Taylor and Bryant, 1985; Morgan and Ask, 2004; Spinelli et al., 2007). Greater-than-expected states of consolidation can result 
from tectonically induced (nonvertical) stress, deformation, cementation, and/or uplift and erosion of overburden, whereas underconsolidation (values less than expected) can be caused by excess pore water pressure (i.e., greater than hydrostatic) and the presence of gas and gas hydrates. Consolidation tests also provide estimates of in situ fluid pressure, permeability, and bulk sediment compressibility (Karig, 1996; Saffer et al., 2000; Stump and Flemings, 2002).

As part of the Nankai Trough Seismogenic Zone Experiment (NanTroSEIZE), we conducted 18 constantrate-of-strain consolidation (CRSC) tests on 17 whole-round (WR) core samples from Integrated Ocean Drilling Program Sites C0002, C0006, and C0007. The sites are located along the Kumano transect offshore south-central Japan (Fig. F1), and they were drilled during Expeditions 315 and 316 (see the "Expedition 315 Site C0002" [Expedition 315 Scientists, 2009], "Expedition 316 Site C0006" [Expedition 316 Scientists, 2009b], and "Expedition 316 Site C0007" [Expedition 316 Scientists, 2009c] chapters). The CRSC tests were conducted to obtain the one-dimensional compression characteristics of the sediments, values of hydraulic conductivity and permeability, and an assessment of the consolidation state (maximum vertical effective stress). We followed essentially the same testing protocols at two institutions: Geotechnical Laboratory at the University of Missouri (MU; USA) and the Rock and Sediment Mechanics Laboratory at The Pennsylvania State University (PSU; USA).

The microfabric of sediments and sedimentary rocks can influence their physical properties and compressibility (Avseth et al., 2000; Sunderland and Morgan, 2003). It is also noteworthy that natural clay-rich sediments and lithified shales show large ranges in permeability values, and this can be attributed to their differences in mineral composition, texture, and grain fabric (Bennett et al., 1991; Neuzil, 1994; Dewhurst et al., 1999; Yang and Aplin, 2007). To gather such information for the NanTroSEIZE samples, we used an environmental scanning electronic microscope (ESEM) to quantify the alignment of grains on faces cut parallel to (vertical) and perpendicular to (horizontal) the core axis.

\section{Methods}

\section{Sample handling and preparation}

All notations and abbreviations for this report are summarized in Table T1. Shipboard coring techniques on the D/V Chikyu include the hydraulic piston coring system (HPCS), rotary core barrel (RCB), and extended shoe coring system (ESCS). The coring system for each sample is shown in its identification code, with $\mathrm{H}$ for HPCS, R for RCB, and X for ESCS. Figures F2 and F3 provide the stratigraphic context for each WR sample interval. Sample intervals range from $32 \mathrm{~m}$ core depth below seafloor (CSF) to $920 \mathrm{~m}$ CSF. Samples from Site C0002 are from the lower forearc basin facies (five samples from Unit II) and the basal starved-basin facies (five samples from Unit III). Samples from Sites C0006 and C0007 are limited to accreted strata within the hanging wall of the frontal thrust; this suite includes trench-wedge deposits (six samples) and the upper Shikoku Basin facies (one sample).

WR core samples typically measure $10-20 \mathrm{~cm}$ in length. They are usually cut within several hours of recovery, capped and taped, sealed with wet sponges in aluminum vacuum bags, and maintained at a temperature of $\sim 4^{\circ} \mathrm{C}$ during shipment and storage to prevent moisture loss prior to the tests. From each WR core, we subsampled homogeneous and intact mud/mudstone after examination of X-ray computed tomography (CT) scans. Immediately prior to testing in the shore-based laboratories, samples are extruded from the core liners and a trimming jig is used to shape the cylinders. Sample diameter for the PSU constant rate of strain (CRS) system is either 50 or $36.6 \mathrm{~mm}$, depending on the required stress levels. The sample diameter for MU tests is fixed at $41 \mathrm{~mm}$. Initial height of a sample in the fixed-wall consolidation ring is $\sim 20 \mathrm{~mm}$ for most PSU tests and $\sim 24 \mathrm{~mm}$ for MU tests (Table T2).

Samples for ESEM imaging of sediment fabric were selected from "clusters" of specimens taken immediately adjacent to WR sample intervals. We cut faces both parallel and perpendicular to the core axis. The orientation of bedding (dip angle with respect to horizontal) for each sample interval is shown on Figures F2 and F3 (see the "Expedition 315 Site C0002" [Expedition 315 Scientists, 2009], "Expedition 316 Site C0006" [Expedition 316 Scientists, 2009b], and "Expedition 316 Site C0007" [Expedition 316 Scientists, 2009c] chapters). These bedding dips are important for relating microfabric anisotropy to in situ orientation of planar features within the deposits.

\section{Index properties}

After trimming each WR sample for a CRSC test, we retained two or three pieces of trimmings for water content measurements. Water content is measured by oven drying the samples to constant mass at $105^{\circ} \mathrm{C}$ (ASTM, 2006). Water content is calculated by taking the difference in the weight of the sample before and after oven drying and dividing the difference by the oven-dried weight (Blum, 1997; see the "Expedition 316 methods" chapter [Expedition 316 Scientists, 2009a]). The calculated values of initial 
void ratio include a correction for salt in the pore water and are reported in Table T2, along with the values of void ratio $(e)$ from the closest sampling interval of a shipboard measurement of moisture and density (MAD). Water content measured in shorebased laboratories can be compared to the shipboard MAD to assess loss of moisture during shipment and storage. In some instances, shore-based $e$ values are higher than shipboard $e$ values; these higher values can be attributed to differences in composition, texture, or disturbance between the nearby sampling intervals.

\section{Constant-rate-of-strain consolidation tests}

We conducted CRSC tests in an oedometer system following the general protocols and test configuration specified by the American Society for Testing and Materials Standard D4186-06 (ASTM, 2006). Samples were trimmed and then placed in a stainless steel specimen ring used to maintain a condition of zero lateral strain. The consolidation cell and lines were then evacuated of air using a vacuum pump, and the specimen was backpressured to values of $u_{\mathrm{b}}=\sim 0.2-0.4 \mathrm{MPa}(\mathrm{MU})$ or $u_{\mathrm{b}}=\sim 0.3-0.4 \mathrm{MPa}$ (PSU) using de-aired synthetic seawater $(1.75 \mathrm{~g} \mathrm{NaCl}$ in $500 \mathrm{~mL}$ distilled water) for $24 \mathrm{~h}$ to ensure saturation and dissolve any air remaining in the system lines. During backpressuring, the axial load was specified to maintain a vertical effective stress $\left(\sigma_{v}^{\prime}\right)$ of $<0.025$ $\mathrm{MPa}$ in the PSU tests, and the axial load actuator maintained a height with a strain of $0.2 \%$ at MU.

Specimens are laterally confined during tests with a fixed-wall consolidation ring. Constant-rate-of-strain loading is applied using a computer-controlled load frame, with the sample base undrained and the sample top open to the backpressure. We continuously monitor the sample height ( $H$, in millimeters), the applied vertical total stress ( $\sigma_{v}$, in kilopascals), and the basal pore pressure ( $u$, in kilopascals). The maximum axial load with the MU loading frame is $44 \mathrm{kN}$; for a specimen with a diameter of $4.14 \mathrm{~cm}$, this corresponds to a maximum vertical total stress of 33 $\mathrm{MPa}$. For pore water backpressure ranging from 0.2 to $0.4 \mathrm{MPa}$, the maximum vertical effective stress is 32.6 to $32.8 \mathrm{MPa}$. The maximum axial load for the PSU device can reach $50 \mathrm{kN}$. Fixed-wall consolidation rings allow for specimen diameters of 25, 36.6, and $50 \mathrm{~mm}$, which correspond to maximum total stresses of $\sim 100, \sim 50$, and $\sim 20 \mathrm{MPa}$, respectively.

Tests are extended to peak axial stresses of $\sim 20 \mathrm{MPa}$ at MU and to either $20 \mathrm{MPa}$ or $40 \mathrm{MPa}$ at PSU (Fig. F5). For each test, we specify the rate of displacement (or strain rate) in order to maintain an anticipated ratio $<0.10$ for basal excess pore pressure $(\Delta u)$ to the total axial stress. Strain rates for the tests are shown in Table T2. Unloading was recorded for a subset of the specimens, and these results are shown as part of the stress-strain and stress-void ratio curves in CRSC in "Supplementary material."

We use the following equations to compute the axial strain $(\varepsilon)$, base excess pore pressure $(\Delta u)$, vertical effective stress $\left(\sigma_{v}^{\prime}\right.$; namely, average effective axial stress within the specimen), hydraulic conductivity $(K)$, intrinsic permeability $(k)$, coefficient of volume compressibility $\left(m_{\mathrm{v}}\right)$, and coefficient of consolidation $\left(C_{v}\right)$ (ASTM, 2006; Long et al., 2008):

$$
\begin{gathered}
\varepsilon=\delta_{\mathrm{n}} / H_{\mathrm{o}} \\
\Delta u=u-u_{\mathrm{b}} \\
\sigma_{v}^{\prime}=\sigma_{\mathrm{v}}-(2 / 3 \times \Delta u), \\
K=\left(\mathrm{d} \varepsilon / \mathrm{dt} \times H_{\mathrm{o}} \times H \times \gamma_{\mathrm{w}}\right) /(2 \times \Delta u), \\
k=(K \times v) /(\rho \times \mathrm{g}), \\
m_{\mathrm{v}}=\Delta \varepsilon / \Delta \sigma_{\mathrm{v}}
\end{gathered}
$$

and

$$
C_{\mathrm{v}}=K /\left(m_{\mathrm{v}} \times \gamma_{\mathrm{w}}\right)
$$

Displacements are measured by a linear variable differential transformer (LVDT) mounted at the top of the consolidation cell and are corrected to account for the compliance of the testing system. Equation 1 defines the natural axial strain of the specimen and is used for subsequent calculations; we report the strain as a percentage in all supplementary tables and figures in CRSC in "Supplementary material." In CRSC tests, permeability values are generally only considered to be reliable once the strain distribution within the sample reaches steady state (ASTM, 2006). To calculate intrinsic permeability from hydraulic conductivity under laboratory testing conditions, we used a value of fluid viscosity $(v)$ equal to $0.001 \mathrm{~Pa} \cdot \mathrm{s}$ for water at $20^{\circ} \mathrm{C}$ (the temperature at which all tests were conducted) and a value of fluid density ( $\rho$ ) equal to $1027 \mathrm{~kg} / \mathrm{m}^{3}$.

As a routine outcome of consolidation tests, comparisons are made between each test-derived value of the maximum pretest consolidation stress $\left(P_{c}^{\prime}\right)$ and a calculated value of in situ hydrostatic vertical effective stress $\left(\sigma_{v h}^{\prime}\right)$ at the equivalent burial depth, assuming conditions of monotonic and uniaxial loading (e.g., Holtz and Kovacs, 1981). We employed two methods to obtain the value of $P^{\prime}{ }_{c}$ for each test: the Casagrande (1936) method, which uses the e $-\log (P)$ curve, and the work (strain energy density) method 
(Becker et al., 1987), which uses the plot of strain energy versus effective stress (Fig. F4). In the case of one-dimensional consolidation, the strain energy density (SED) is calculated by

$$
\operatorname{SED}=\left[\left(\sigma_{\mathrm{vL}-1}^{\prime}+\sigma_{\mathrm{vL}}^{\prime}\right) / 2\right] \times \ln \left[\left(1-\varepsilon_{\mathrm{L}-1}\right) /\left(1-\varepsilon_{\mathrm{L}}\right)\right] .
$$

SED is the work per unit volume done by the effective stress (Becker et al., 1987; Germaine and Germaine, 2009).

The depth gradient for hydrostatic vertical effective stress at each site is calculated by subtracting the values of hydrostatic pore pressure from the overburden stress (total normal stress). The overburden stress is constrained by integrating the shipboard bulk density and depth data (see the "Expedition 315 Site C0002" [Expedition 315 Scientists, 2009], "Expedition 316 Site C0006" [Expedition 316 Scientists, 2009b], and "Expedition 316 Site C0007" [Expedition 316 Scientists, 2009c] chapters). For a normally consolidated specimen, the test-derived and calculated values of $P^{\prime}{ }_{c}$ and $\sigma_{\mathrm{vh}}^{\prime}$ are equal. Overconsolidation refers to a case in which the value of $P^{\prime}{ }_{c}$ exceeds the calculated value of $\sigma_{v h}^{\prime}$ at the depth from which the specimen was cored, and underconsolidation refers to a situation in which $P^{\prime}{ }_{c}$ is less than $\sigma^{\prime}{ }_{v h}$. We used a graphical solution to pick the associated values of void ratio at the points where $P^{\prime}{ }_{c}$ and $\sigma^{\prime}{ }_{v h}$ intersect the consolidation curves.

\section{Microfabric analysis}

Instrument settings for the FEI Quanta 600 FEG scanning electron microscope follow the procedures described by Yue et al. (submitted). The images are taken from wet, uncoated specimens with an imaging resolution of $\sim 4 \mathrm{~nm}$, and the dimensions of the field of view are $\sim 145$ by $130 \mu$ m with $2000 \times$ magnification. The approach used for quantification of the specimen's microfabric follows the graphic standard deviation (sorting) statistics of Folk and Ward (1957), as described in more detail by Yue et al. (submitted). After processing each digital SEM image, we construct cumulative frequency curves to show the angle of apparent long axes for particles oriented from $0^{\circ}$ to $180^{\circ}$ across imaging surfaces, with those surfaces cut parallel and perpendicular to the core axis. The standard deviation of particle orientation $(d)$ equals

$$
d=\left[\left(\phi_{84}-\phi_{16}\right) / 4\right]+\left[\left(\phi_{95}-\phi_{5}\right) / 6.6\right],
$$

where $\phi_{84}, \phi_{16}, \phi_{95}$, and $\phi_{5}$ represent the graphic picks for the angles of particle orientation at the eightyfourth, sixteenth, ninety-fifth, and fifth percentiles, respectively, on the cumulative frequency curve.
This graphic statistic avoids the laborious calculations required by moment statistics (Chiou et al., 1991). Numerically, the maximum value of $d$ is equal to $72.3^{\circ}$ (i.e., a case in which $\phi_{84}=180, \phi_{16}=0, \phi_{95}=180$, and $\left.\phi_{5}=0\right)$. Each $d$ value is normalized to this maximum value by calculating the index of orientation (i), as defined by the following formula:

$$
i=1-(d / 72.3) \text {. }
$$

We also display fabric results using rose diagrams to illustrate the number of grains (apparent long axes) aligned within each $10^{\circ}$ orientation bin from $0^{\circ}$ to $180^{\circ}$ across the imaging surface. If the fabric of a sedimentary deposit shows strong preferred grain orientation relative to the core axis, then the standard deviation of orientation will be smaller, the slope of cumulative frequency curve will be steeper near the mode, the curve will be more nonlinear, and the index of orientation will be closer to 1 . Interpretations of these results (e.g., differences between horizontal and vertical faces) need to take the dip of bedding into account, as shown in Figures F2 and F3.

\section{Results}

Sample identification and a summary of CRSC test results are shown in Table T2. A complete CRSC data sheet can be found for each test in CRSC in "Supplementary material." Figures in CRSC in "Supplementary material" show time series data of vertical effective stress $\left(\sigma_{v}^{\prime}\right)$ and basal excess pore pressure $(\Delta u)$ for all the tests, the consolidation curves in e $\log \left(\sigma_{\mathrm{v}}^{\prime}\right)$ and $\varepsilon-\log \left(\sigma_{\mathrm{v}}^{\prime}\right)$ formats, excess pore pressure ratio, coefficient of consolidation $\left(C_{\mathrm{v}}\right)$, SED, and hydraulic conductivity $(K)$ for each CRSC test.

The graphical determination of a $P^{\prime}{ }_{\mathrm{c}}$ value is not reliable unless the inflection point on the e $-\log (\mathrm{P})$ curve is clearly defined. The effect of sample disturbance on test quality was evaluated following the criteria of Lunne et al. (1997). This designation considers the overconsolidation ratio (OCR), where OCR is equal to $P^{\prime}{ }_{c} / \sigma^{\prime}{ }_{v h}$, plus the change of void ratio during consolidation tests. The $\Delta e$ value is equal to the difference between the initial pretest void ratio $\left(e_{\mathrm{i}}\right)$ and the void ratio at the intersection point of $P^{\prime}{ }_{c}$ on the consolidation curve using the SED method. The rating is based on $\Delta e / e_{\mathrm{i}}$. Sample quality is poor to very poor for most specimens (Table T3). Disturbance is particularly severe for the specimens from Site C0006.

$P^{\prime}{ }_{c}$ values are similar using the Casagrande and SED approaches (Table T2). All specimens from Sites C0002, C0006, and C0007 exhibit significant 
amounts of apparent overconsolidation (Fig. F5). In other words, the test-derived values of $P^{\prime}{ }_{c}$ are greater than the calculated values of in situ hydrostatic vertical effective stress $\left(\sigma^{\prime}{ }_{\mathrm{vh}}\right)$ at the sampling depths. Differences between values of $P_{c}^{\prime}$ and $\sigma_{v h}^{\prime}$ range from 0.31 to $9.14 \mathrm{MPa}$. The overconsolidation ratio based on SED-determined values of $P_{c}{ }_{c}$ varies from 1.69 to 8.58.

The compression index $\left(C_{c}\right)$ refers to the slope of the virgin portion of the $\mathrm{e}-\log (\mathrm{P})$ curve (Fig. F4). The index is calculated using the following equation:

$$
C_{\mathrm{c}}=\left(e_{1}-e_{2}\right) /\left(\log \sigma_{\mathrm{v} 1}^{\prime}-\log \sigma_{\mathrm{v} 2}^{\prime}\right) \text {. }
$$

Values of $C_{c}$ range from 0.390 to 0.780 (average $=0.584$ ) at Site C0002. Values of $C_{\mathrm{c}}$ at Sites C0006 and C0007 range from 0.236 to 0.418 (average $=0.302$ ) in the trench-wedge and upper Shikoku Basin facies (Table T2). Calculated values of intrinsic permeability decrease during CRSC tests as vertical effective stress increases and porosity is progressively lost (Fig. F6). Permeability values for strata from Site C0002 show log-linear decreases with porosity. Values decrease from a range of $6.53 \times 10^{-17}$ to $9.83 \times 10^{-16} \mathrm{~m}^{2}$ at porosities of $52 \%$ to $54 \%\left(\sigma_{v}^{\prime}=1-2 \mathrm{MPa}\right)$ to a range of $1.50 \times 10^{-19}$ to $3.72 \times 10^{-19} \mathrm{~m}^{2}$ at porosities of $16 \%$ to $22 \%\left(\sigma^{\prime}{ }_{v}=40\right.$ $\mathrm{MPa})$. A plot of permeability versus porosity for Sites C0006 and C0007 also exhibits a log-linear trend. Values decrease from a range of $4.11 \times 10^{-18}$ to $2.00 \times$ $10^{-15} \mathrm{~m}^{2}$ at porosities of $43 \%$ to $46 \%\left(\sigma_{\mathrm{v}}^{\prime}=1-2 \mathrm{MPa}\right)$ to a range of $3.28 \times 10^{-19}$ to $1.59 \times 10^{-17} \mathrm{~m}^{2}$ at porosities of $12 \%$ to $19 \%\left(\sigma_{v}^{\prime}=20 \mathrm{MPa}\right)$.

We calculated the in situ intrinsic permeability of each sample from the in situ void ratio and the porosity values shown in Table T4. We obtained those values by extrapolating the linear portion of the $\mathrm{n}-$ $\log (k)$ relation to the porosity and equivalent void ratio to match a desired value of $P_{c}^{\prime}$ or $\sigma_{v h}^{\prime}$ on the SED curves (Fig. F6) (e.g., Long et al., 2008). There is no consistent trend of intrinsic permeability changing with depth at Site C0002; values range from $2.67 \times 10^{-17}$ to $2.56 \times 10^{-18} \mathrm{~m}^{2}$ (Fig. F7). In situ intrinsic permeability deceases systematically with depth at Sites C0006 and C0007 from values of $1.85 \times 10^{-16} \mathrm{~m}^{2}$ at $33 \mathrm{~m} \mathrm{CSF}$ to values of $5.61 \times 10^{-17} \mathrm{~m}^{2}$ at $400 \mathrm{~m} \mathrm{CSF}$ (Fig. F7).

We also calculated in situ hydraulic conductivity from values of in situ intrinsic permeability by taking into account changes in temperature, fluid density, and fluid viscosity with depth (Table T4). Temperature-dependent changes in permeant properties assume a pore water salinity of $35 \%$ and follow the equations of El-Dessouky and Ettouny (2002) and Fofonoff (1985).
The statistics used to evaluate microfabric are summarized in Table T5. Figure F8 shows all ESEM images for the horizontal and vertical sections of the samples. Figure F9 shows the orientations of the particles (apparent long axes) as rose diagrams, together with values of standard deviation and index of orientation. Cumulative curves are shown in Figure F10. Average values for index of orientation are $\sim 0.33$ (Sites C0006 and C0007) and 0.38 (Site C0002). This index is expected to increase as depth of burial increases. Vertical sections generally show greater indexes of orientation than the horizontal sections, which should be expected as mudstones develop a weak bedding-parallel fissility. Exceptions to this pattern include several samples from Sites C0006 and C0007 where bedding dips are $>40^{\circ}$ (Table T5; Fig. F9). Samples from Site $\mathrm{COOO2}$ and the accreted upper Shikoku Basin facies at $\mathrm{C0007}$ yielded the highest values of orientation index $(>0.40)$, indicating better preferred alignment of platy grains. Plots of the index of orientation versus $C_{\mathrm{c}}$ and $P^{\prime}{ }_{\mathrm{c}}$ show weak positive correlations (Fig. F11), which indicates that the mudstone microfabric has very little influence on the state of consolidation over the range of burial depths covered by this study.

\section{Acknowledgments}

This research used samples provided by the Integrated Ocean Drilling Program (IODP). We thank Captains Ichiyama and Onda, as well as the drilling crew, laboratory technicians, and fellow scientists aboard the D/V Chikyu for their dedicated assistance during IODP Expeditions 315 and 316. Funding was granted by the Consortium for Ocean Leadership, U.S. Science Support Program (grants T315A58, T315B58, and T315C58) and the National Science Foundation (grants OCE-07518190 to MU and OCE0752114 to PSU). Burns and McDonnell provided a generous contribution toward acquisition of the CRS system at the University of Missouri, and Lou Ross provided guidance on ESEM imaging. B. Dugan provided a helpful review of the manuscript.

\section{References}

ASTM International, 2006. Standard test method for onedimensional consolidation properties of saturated cohesive soils using controlled-strain loading (Standard D4186-06). In Annual Book of ASTM Standards (Vol. 04.08): Soil and Rock (I): West Conshohocken, PA (Am. Soc. Testing Mater.)

Avesth, P., Dvorkin, J., Mavko, G., and Rykkje, J., 2000. Rock physics diagnostic of North Sea sands: link between microstructure and seismic properties. Geophys. 
Res. Lett., 27(17):2761-2764. doi:10.1029/ 1999GL008468

Becker, D.E., Crooks, J.H.A., Been, K., and Jeffries, M.G., 1987. Work as a criterion for determining in situ and yield stresses in clays. Can. Geotech. J., 24(4):549-564. doi:10.1139/t87-070

Bennett, R.H., O’Brien, N.R., and Hulbert, M.H., 1991. Determinants of clay and shale microfabric signatures: processes and mechanisms. In Bennett, R.H., Bryant, W.R., and Hulbert, M.H. (Eds.), Microstructure of FineGrained Sediments: From Mud to Shale: New York (Springer-Verlag), 5-32.

Blum, P., 1997. Physical properties handbook: a guide to the shipboard measurement of physical properties of deep-sea cores. ODP Tech. Note, 26. doi:10.2973/ odp.tn.26.1997

Casagrande, A., 1936. The determination of pre-consolidation load and its practical significance. In Casagrande, A., Rutledge, P.C., and Watson, J.D. (Eds.), Proc. 1st Int. Conf. Soil Mech. Found. Eng. Am. Soc. Civ. Eng., 3:60-64.

Carson, B., 1977. Tectonically induced deformation of deep-sea sediments off Washington and northern Oregon: mechanical consolidation. Mar. Geol., 24(4):289307. doi:10.1016/0025-3227(77)90073-1

Chiou, W.A., Bryant, W.R., and Bennett, R.H., 1991. Quantification of clay fabric: a simple technique. In Bennett, R.H., Bryant, W.R., and Hulbert, M.H. (Eds.), Microstructure of Fine-Grained Sediments: From Mud to Shale: New York (Springer-Verlag), 379-387.

Dewhurst, D.N., Yang, Y., and Aplin, A.C., 1999. Permeability and fluid flow in natural mudstones. In Aplin, A.C., Fleet, A.J., and MacQuaker, J.H.S. (Eds.), Muds and Mudstones: Physical and Fluid-Flow Properties. Geol. Soc. Spec. Publ., 158(1):23-43. doi:10.1144/ GSL.SP.1999.158.01.03

El-Dessouky, H.T., and Ettouney, H.M., 2002. Fundamentals of Salt Water Desalination: Amsterdam (Elsevier)

Expedition 315 Scientists, 2009. Expedition 315 Site C0002. In Kinoshita, M., Tobin, H., Ashi, J., Kimura, G., Lallemant, S., Screaton, E.J., Curewitz, D., Masago, H., Moe, K.T., and the Expedition 314/315/316 Scientists, Proc. IODP, 314/315/316: Washington, DC (Integrated Ocean Drilling Program Management International, Inc.). doi:10.2204/iodp.proc.314315316.124.2009

Expedition 316 Scientists, 2009a. Expedition 316 methods. In Kinoshita, M., Tobin, H., Ashi, J., Kimura, G., Lallemant, S., Screaton, E.J., Curewitz, D., Masago, H., Moe, K.T., and the Expedition 314/315/316 Scientists, Proc. IODP, 314/315/316: Washington, DC (Integrated Ocean Drilling Program Management International, Inc.). doi:10.2204/iodp.proc.314315316.132.2009

Expedition 316 Scientists, 2009b. Expedition 316 Site C0006. In Kinoshita, M., Tobin, H., Ashi, J., Kimura, G., Lallemant, S., Screaton, E.J., Curewitz, D., Masago, H., Moe, K.T., and the Expedition 314/315/316 Scientists, Proc. IODP, 314/315/316: Washington, DC (Integrated Ocean Drilling Program Management International, Inc.). doi:10.2204/iodp.proc.314315316.134.2009

Expedition 316 Scientists, 2009c. Expedition 316 Site C0007. In Kinoshita, M., Tobin, H., Ashi, J., Kimura, G.,
Lallemant, S., Screaton, E.J., Curewitz, D., Masago, H., Moe, K.T., and the Expedition 314/315/316 Scientists, Proc. IODP, 314/315/316: Washington, DC (Integrated Ocean Drilling Program Management International, Inc.). doi:10.2204/iodp.proc.314315316.135.2009

Fofonoff, N.P., 1985. Physical properties of seawater: a new salinity scale and equation of state for seawater. J. Geophys. Res., [Oceans], 90(C2):3332-3342. doi:10.1029/ JC090iC02p03332

Folk, R.L., and Ward, W.C., 1957. Brazos River bar [Texas]: a study in the significance of grain size parameters. $J$. Sediment. Res., 27(1):3-26. http://jsedres.sepmonline.org/cgi/content/abstract/27/1/3

Germaine, J.T., and Germaine, A.V., 2009. Geotechnical Laboratory Measurements for Engineers: Hoboken, NJ (Wiley).

Holtz, R.D., and Kovacs, W.D., 1981. An Introduction to Geotechnical Engineering: Englewood Cliffs, NJ (Prentice-Hall).

Karig, D.E., 1996. Uniaxial reconsolidation tests on porous sediments: mudstones from Site 897. In Whitmarsh, R.B., Sawyer, D.S., Klaus, A., and Masson, D.G. (Eds.), Proc. ODP, Sci. Results, 149: College Station, TX (Ocean Drilling Program), 363-373. doi:10.2973/ odp.proc.sr.149.234.1996

Lee, H.J., Olsen, H.W., and von Huene, R., 1973. Physical properties of deformed sediments from Site 181. In Kulm, L.D., von Huene, R., et al., Init. Repts. DSDP, 18: Washington (U.S. Govt. Printing Office), 897-901. doi:10.2973/dsdp.proc.18.127.1973

Long, H., Flemings, P.B., Germaine, J.T., Saffer, D.M., and Dugan, B., 2008. Data report: consolidation characteristics of sediments from IODP Expedition 308, Ursa Basin, Gulf of Mexico. In Flemings, P.B., Behrmann, J.H., John, C.M., and the Expedition 308 Scientists, Proc. IODP, 308: College Station, TX (Integrated Ocean Drilling Program Management International, Inc.). doi:10.2204/ iodp.proc.308.204.2008

Lunne, T., Berre, T., and Strandvik, S., 1997. Sample disturbance effects in soft low plastic Norwegian clay. Publ.Nor. Geotek. Inst., 204:81-102.

Morgan, J.K., and Ask, M.V.S., 2004. Consolidation state and strength of underthrust sediments and evolution of the décollement at the Nankai accretionary margin: results of uniaxial reconsolidation experiments. J. Geophys. Res., [Solid Earth], 109(B3):B03102. doi:10.1029/ 2002JB002335

Neuzil, C.E., 1994. How permeable are clays and shales? Water Resour. Res., 30(2):145-150. doi:10.1029/ 93WR02930

Saffer, D.M., Silver, E.A., Fisher, A.T., Tobin, H., and Moran, K., 2000. Inferred pore pressures at the Costa Rica subduction zone: implications for dewatering processes. Earth Planet. Sci. Lett., 177(3-4):193-207. doi:10.1016/ S0012-821X(00)00048-0

Shephard, L.E., and Bryant, W.R., 1980. Consolidation characteristics of Japan Trench sediments. In von Huene, R., Nasu, N., et al., Init. Repts. DSDP, 56, 57: Washington, DC (U.S. Govt. Printing Office), 12011205. doi:10.2973/dsdp.proc.5657.152.1980

Spinelli, G.A., Mozley, P.S., Tobin, H.J., Underwood, M.B., Hoffman, N.W., and Bellew, G.M., 2007. Diagenesis, sedi- 
ment strength, and pore collapse in sediment approaching the Nankai Trough subduction zone. Geol. Soc. Am. Bull., 119(3-4):377-390. doi:10.1130/B25920.1

Stump, B.B., and Flemings, P.B., 2002. Consolidation state, permeability, and stress ratio as determined from uniaxial strain experiments on mudstone samples from the Eugene Island 330 area, offshore Louisiana. In Huffman, A.R., and Bowers, G.L. (Eds.), Pressure Regimes in Sedimentary Basins and their Prediction. AAPG Mem., 76:131144.

Sunderland, E.B., and Morgan, J.K., 2004. Microstructural variations in sediments from the toe of the Nankai accretionary prism: results of scanning electron microscope analysis. In Mikada, H., Moore, G.F., Taira, A., Becker, K., Moore, J.C., and Klaus, A. (Eds.), Proc. ODP, Sci. Results, 190/196: College Station, TX (Ocean Drilling Program), 1-27. doi:10.2973/

odp.proc.sr.190196.212.2004

Taylor, E., and Bryant, W.R., 1985. Geotechnical properties of sediments from the Middle America Trench and slope. In von Huene, R., Aubouin, J., et al., Init. Repts. DSDP, 84: Washington, DC (U.S. Govt. Printing Office), 745-766. doi:10.2973/dsdp.proc.84.132.1985
Trabant, P.K., Bryant, W.R., and Bouma, A.H., 1975. Consolidation characteristics of sediments from Leg 31 of the Deep Sea Drilling Project. In Karig, D.E., Ingle, J.C., Jr., et al., Init. Repts. DSDP, 31: Washington, DC (U.S. Govt. Printing Office), 569-572. doi:10.2973/ dsdp.proc.31.122.1975

Yang, Y., and Aplin, A.C., 2007. Permeability and petrophysical properties of 30 natural mudstones. J. Geophys. Res., 112(B3):B03206. doi:10.1029/2005JB004243

Yue, L., Likos, W.J., Guo, J., and Underwood, M.B., submitted. Data report: permeability of mud(stone) samples from Site C0001, IODP Expedition 315, Nankai Trough: Stage 1 of NanTroSEIZE. In Kinoshita, M., Tobin, H., Ashi, J., Kimura, G., Lallemant, S., Screaton, E.J., Curewitz, D., Masago, H., Moe, K.T., and the Expedition 314/ 315/316 Scientists, Proc. IODP, 314/315/316: Washington, DC (Integrated Ocean Drilling Program Management International, Inc.).

Initial receipt: 21 October 2010

Acceptance: 23 May 2011

Publication: 5 October 2011

MS 314315316-213 
Figure F1. A. Map of the Kumano transect region with NanTroSEIZE Stage 1 drill sites. B. Seismic inline section from 3-D survey showing locations of Sites C0002, C0006, and C0007 (from the "Expedition 315 Site C0002" [Expedition 315 Scientists, 2009], "Expedition 316 Site C0006" [Expedition 316 Scientists, 2009b], and "Expedition 316 Site C0007" [Expedition 316 Scientists, 2009c] chapters). C. Sample locations at Site C0002 (red boxes) plotted on seismic section. D. Sample locations at Sites C0006 and C0007 (red boxes) plotted on seismic section.

\section{A}
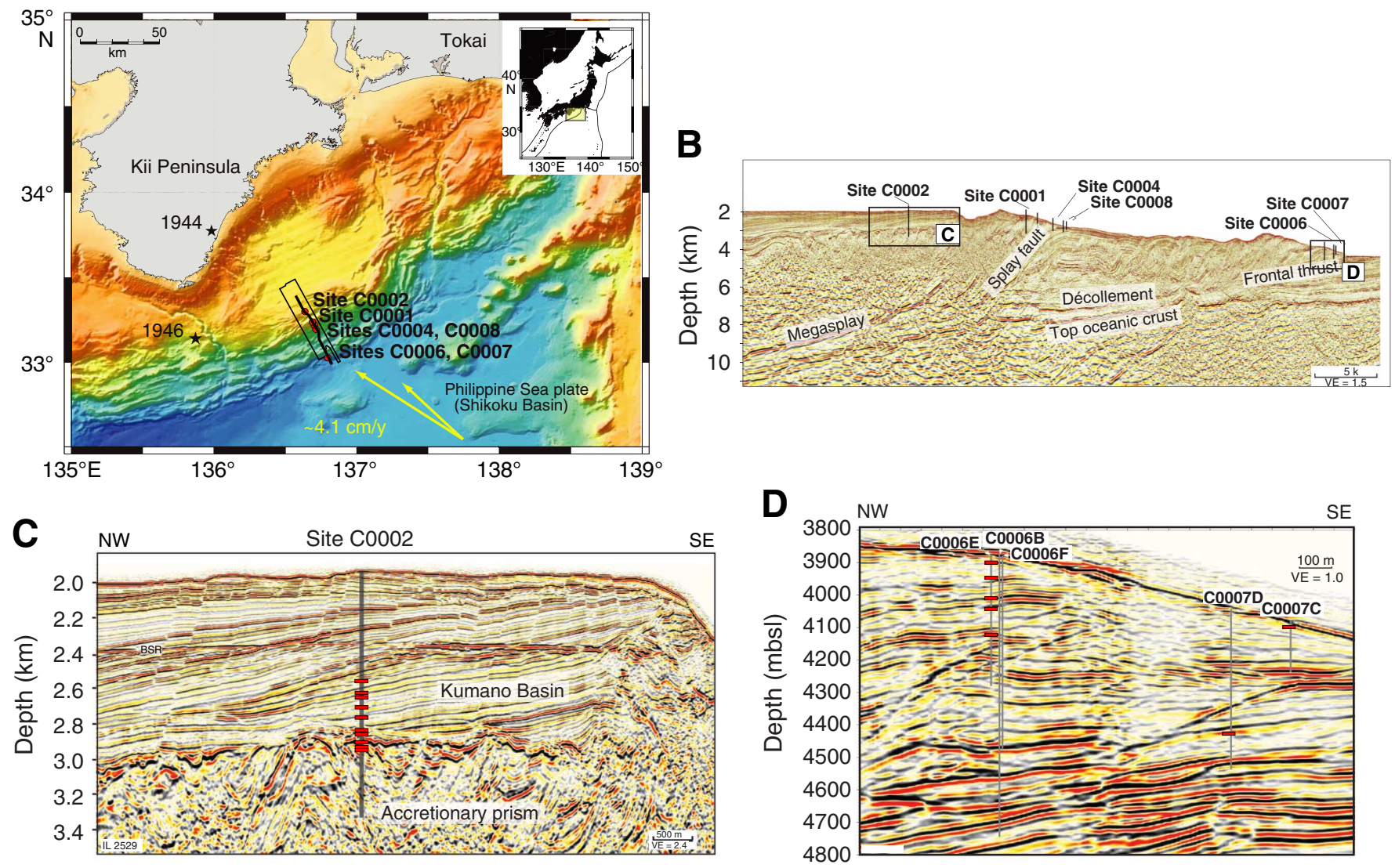
Figure F2. Lithostratigraphy of Site C0002 showing sample locations (red symbols) and dips of bedding (from the "Expedition 315 Site C0002" chapter [Expedition 315 Scientists, 2009]).

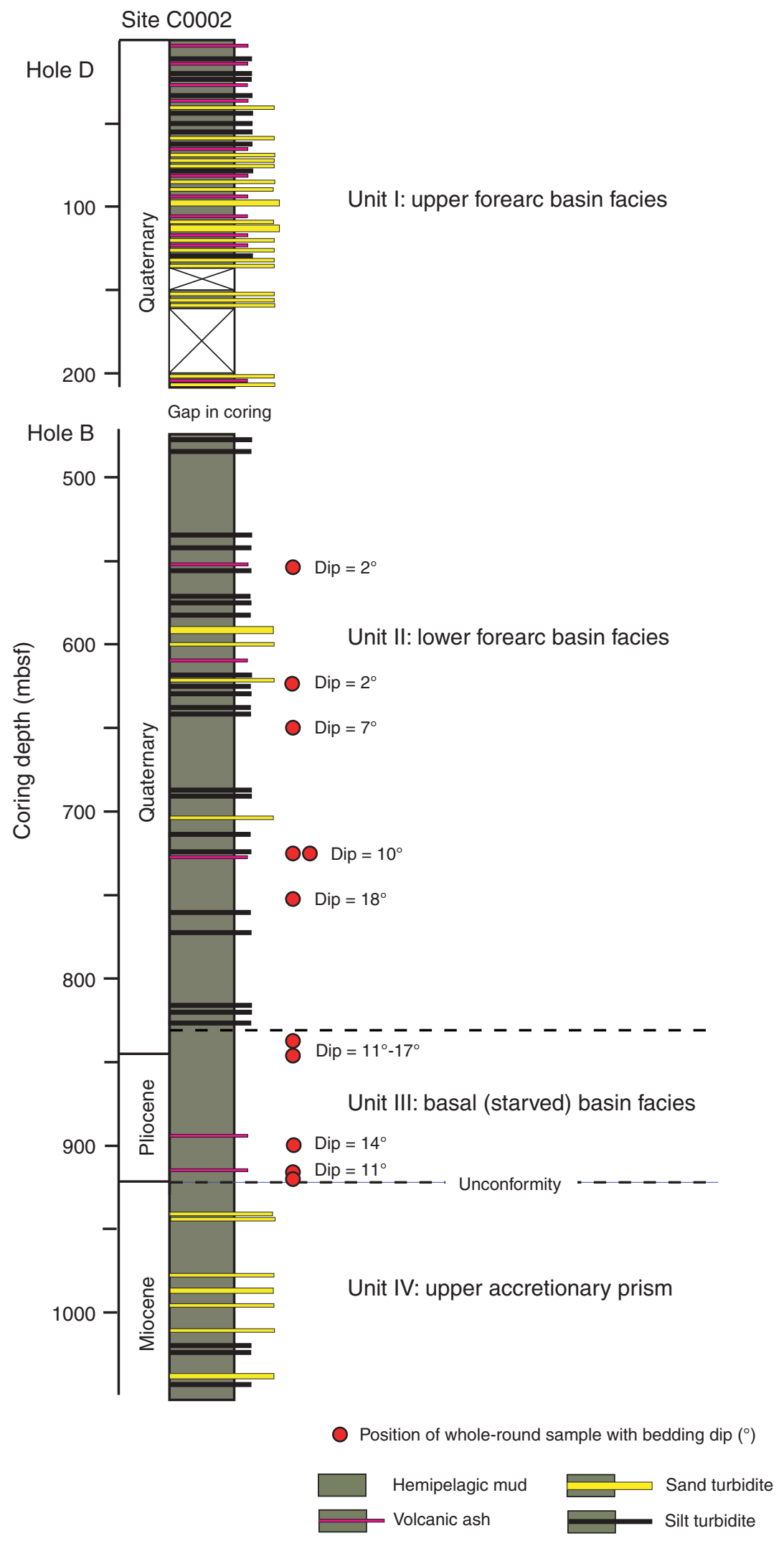


Figure F3. Lithostratigraphy of Sites C0006 and C0007 showing sample locations (red symbols) and dips of bedding (from the "Expedition 316 Site C0006" [Expedition 316 Scientists, 2009b] and "Expedition 316 Site C0007" [Expedition 316 Scientists, 2009c] chapters).

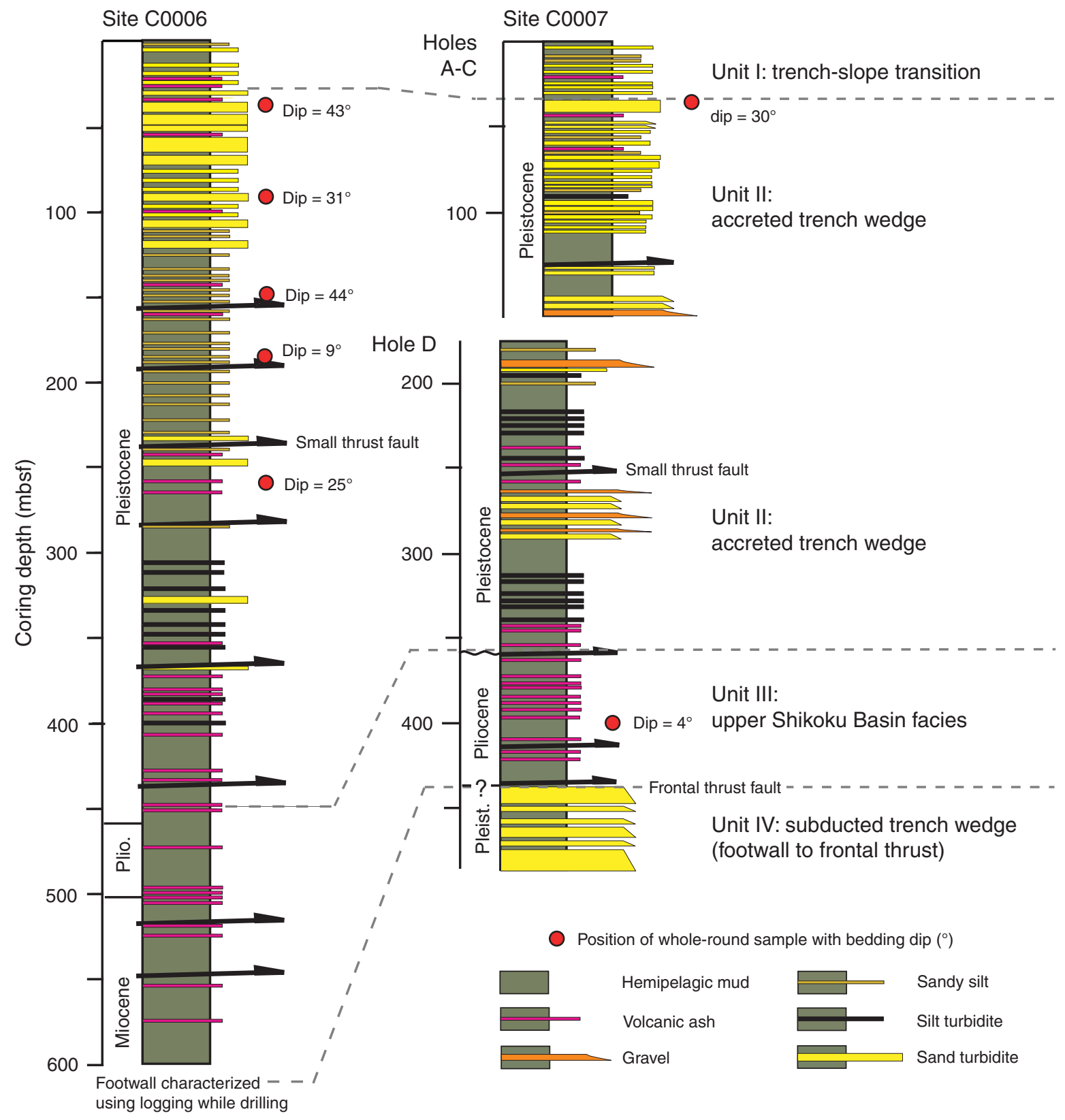


Figure F4. Illustration of methods to determine the maximum value of vertical effective stress $\left(P_{c}^{\prime}\right)$ from the results of CRSC tests. Plot of void ratio vs. vertical effective stress shows determination of $P^{\prime}{ }_{\mathrm{c}}$ following Casagrande (1936). Plot of strain energy density vs. vertical effective stress shows the work (SED) method of Becker et al. (1987), where $P^{\prime}{ }_{c}$ is defined by the intersection of line segments fit to the initial slope of the reloading curve (enlarged in insert) and to the virgin compression curve.
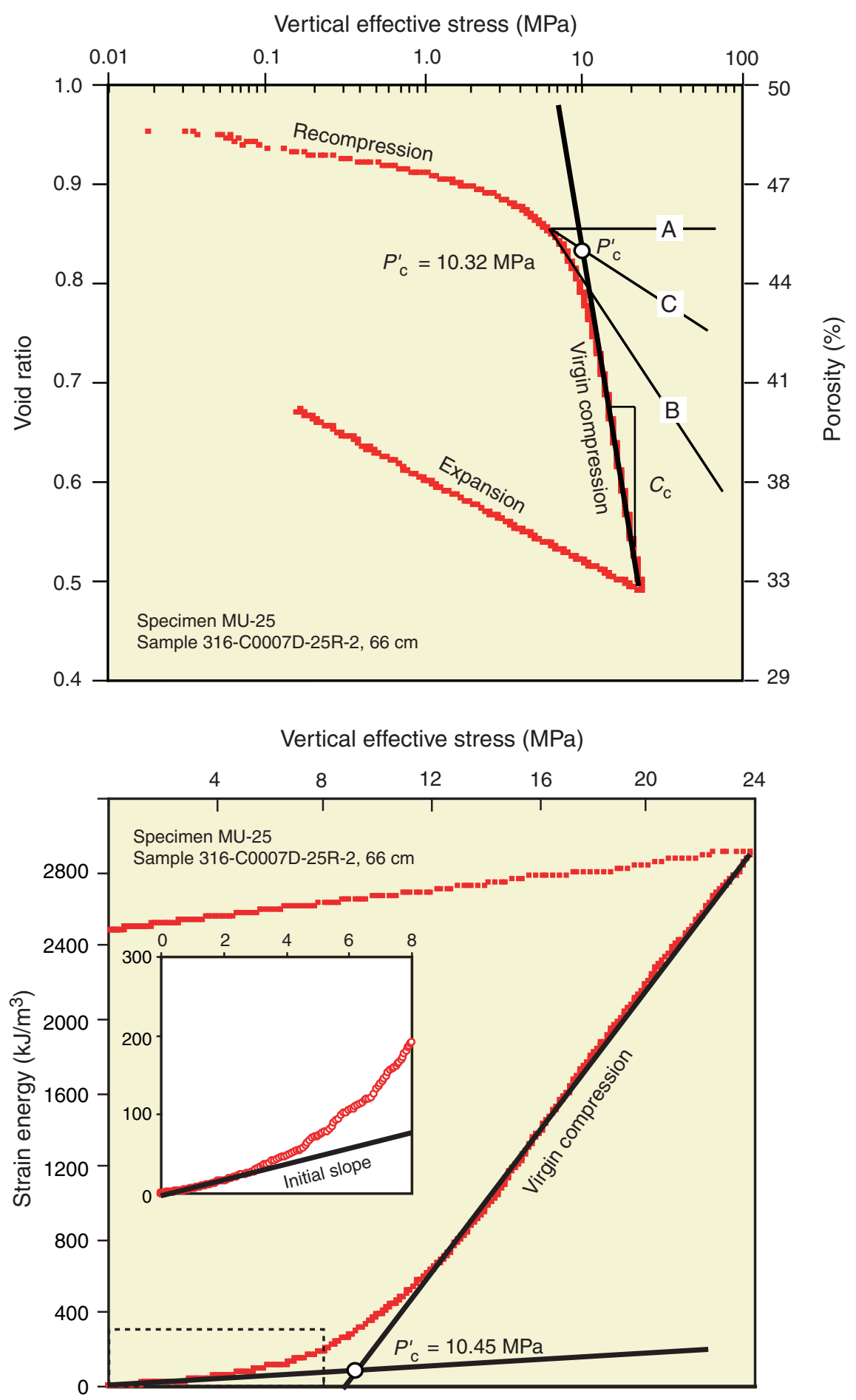
Figure F5. Plot of $P^{\prime}{ }_{c}$ values from CRSC tests (Fig. F4) vs. burial depth at Sites C0002, C0006, and C0007. Reference curves for hydrostatic vertical effective stress $\sigma_{v h}^{\prime}$ at each site were derived by subtracting hydrostatic pore pressure from the values of total normal stress exerted by overburden. Overburden stress is constrained by integrating the shipboard bulk density and depth data (see the "Expedition 315 Site C0002" [Expedition 315 Scientists, 2009], "Expedition 316 Site C0006" [Expedition 316 Scientists, 2009b], and "Expedition 316 Site C0007" [Expedition 316 Scientists, 2009c] chapters).
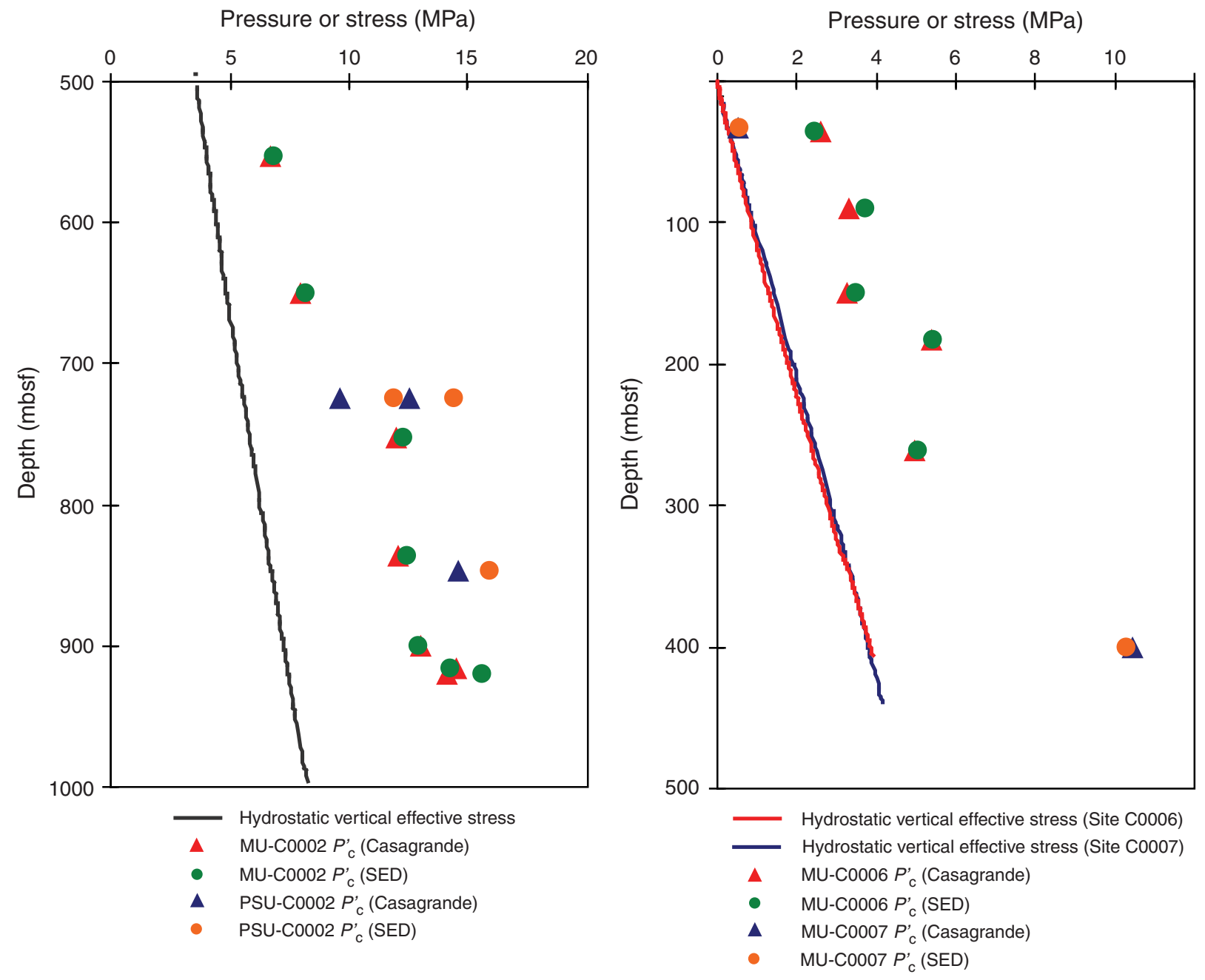
Figure F6. Intrinsic permeability values obtained during CRSC tests (equation 4) plotted as a function of vertical effective stress and porosity. Specimens are from Sites C0002, C0006, and C0007.
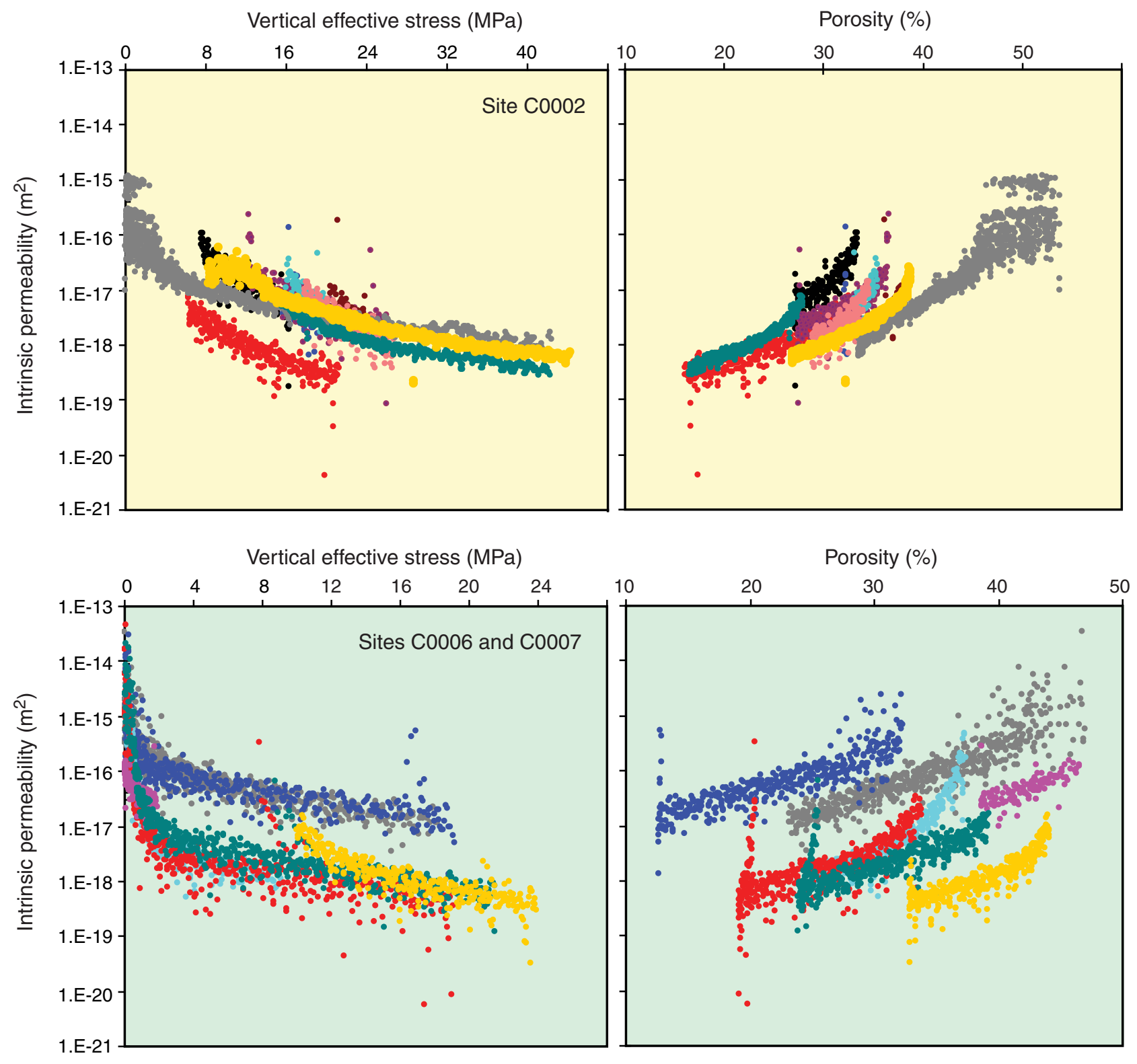
Figure F7. Estimates of intrinsic permeability plotted as a function of in situ depth for Sites C0002, C0006, and C0007. Values were determined by projecting the permeability-porosity curve for each mudstone sample to the equivalent value of in situ void ratio obtained for the points at $P^{\prime}{ }_{\mathrm{c}}$ (SED method) and $\sigma_{\mathrm{vh}}^{\prime}$ (Fig. F5). In situ permeant properties are listed in Table T4.
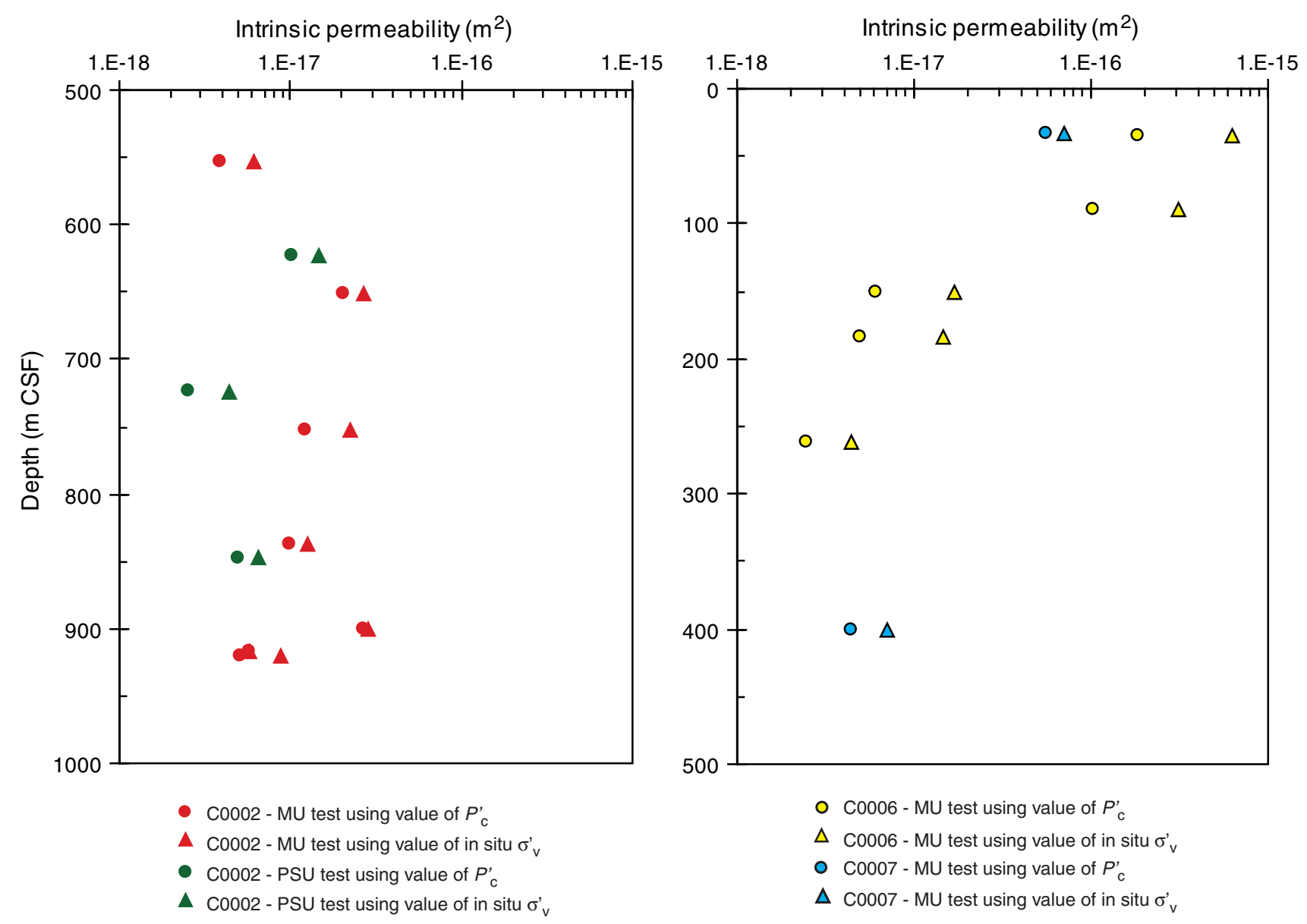
Figure F8. Environmental SEM images of horizontal and vertical sections of samples from Sites C0002, C0006, and C0007. (Continued on next four pages.)
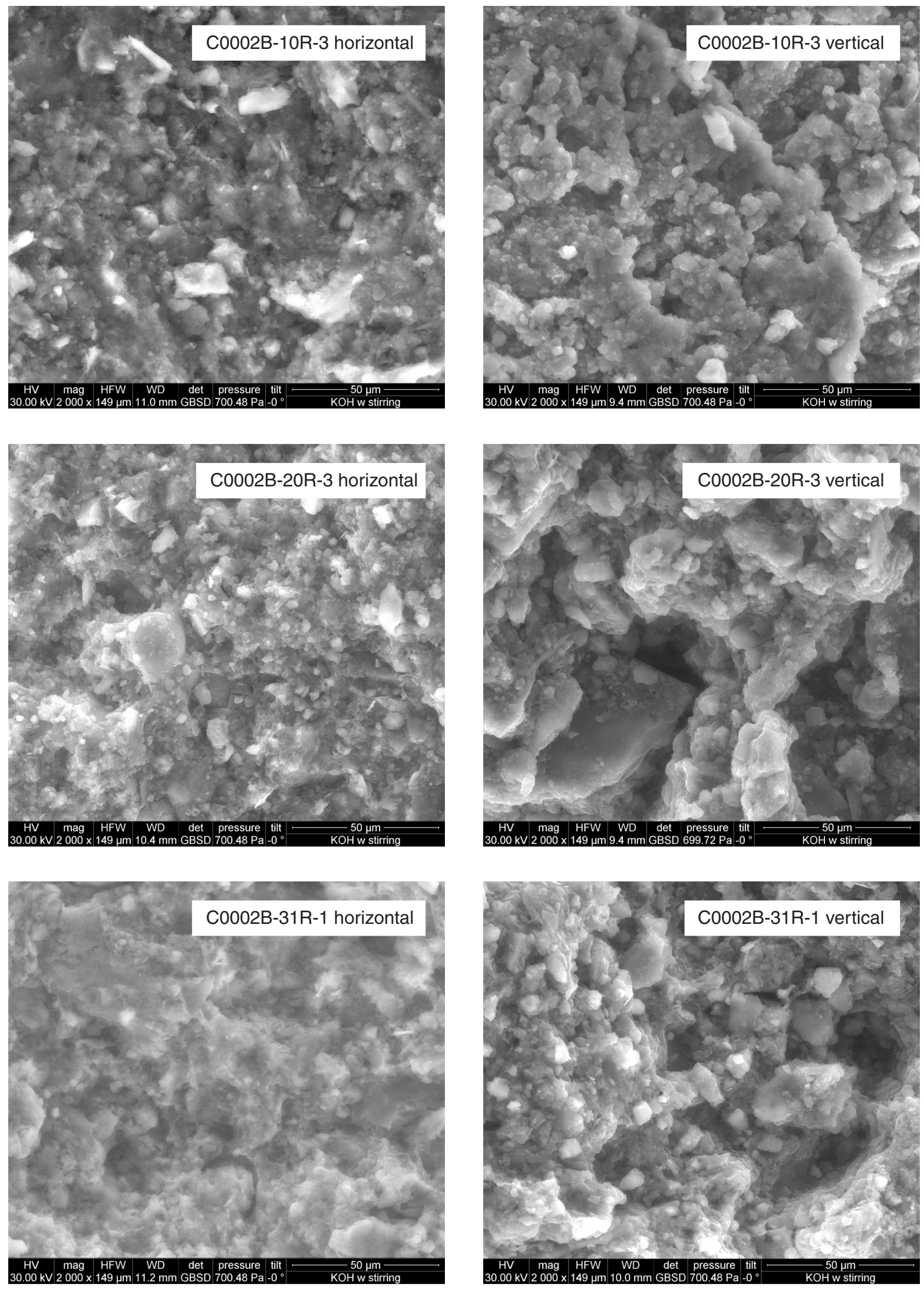
Figure F8 (continued).
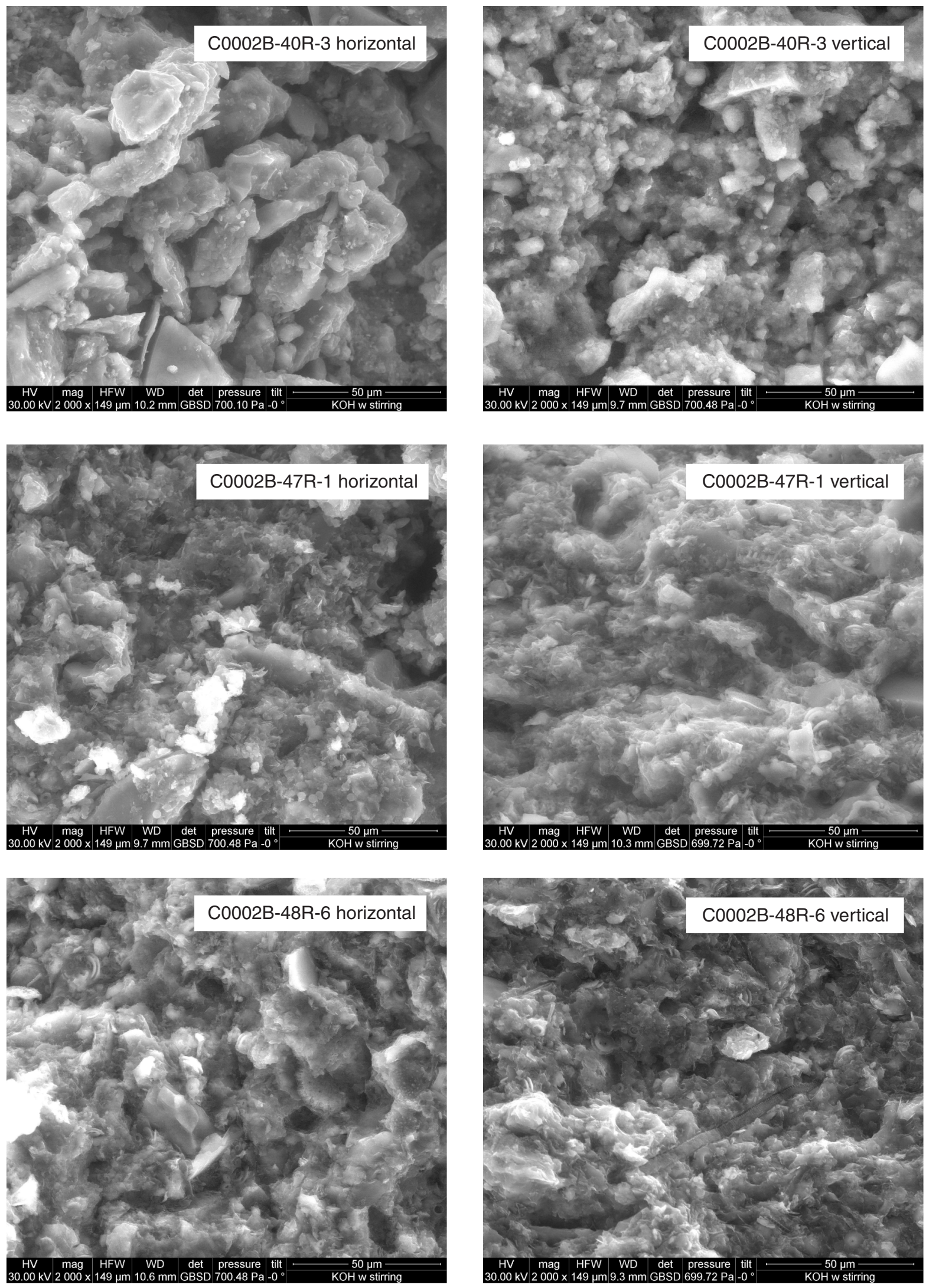


\section{Figure F8 (continued).}
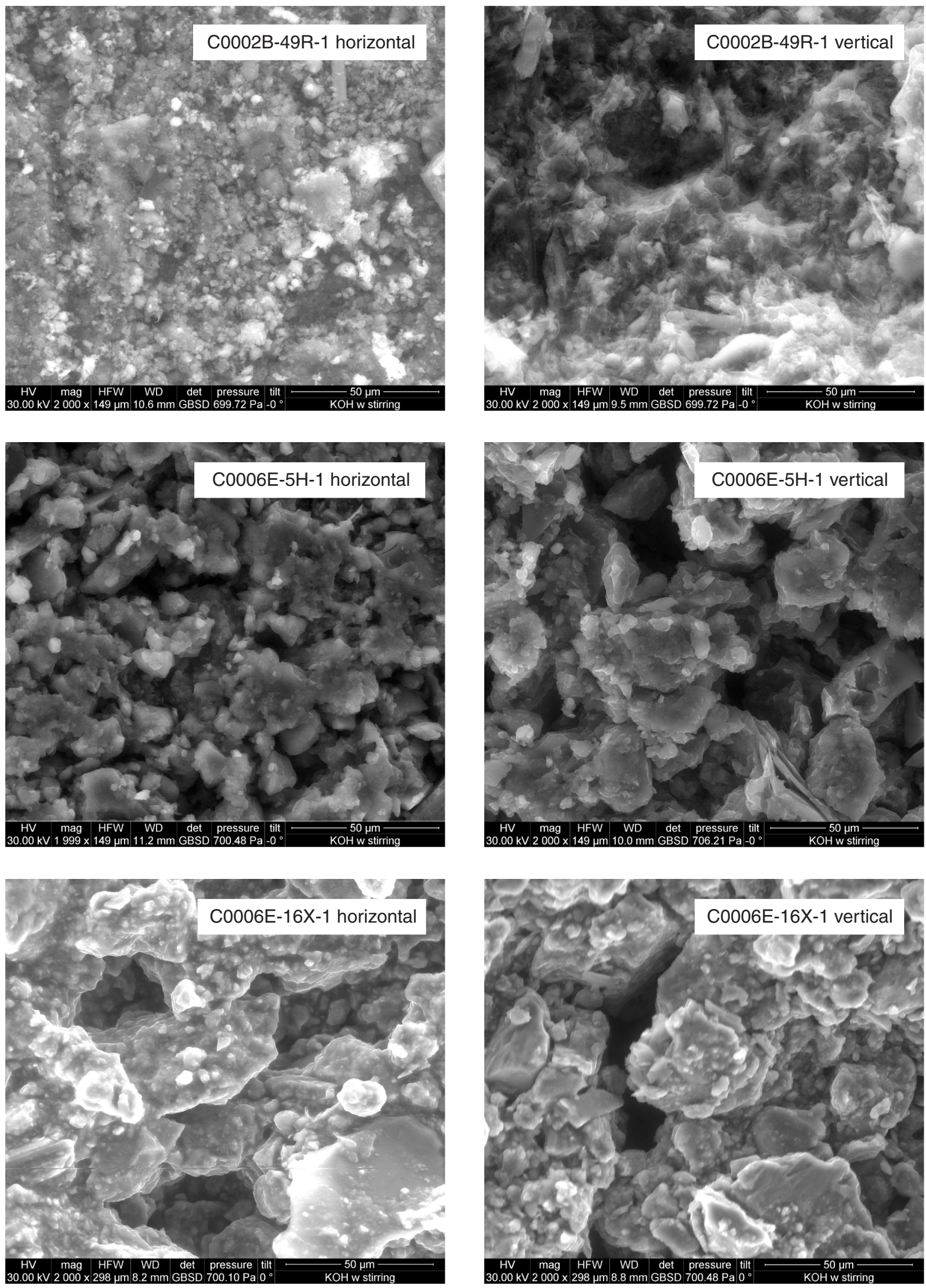
Figure F8 (continued).
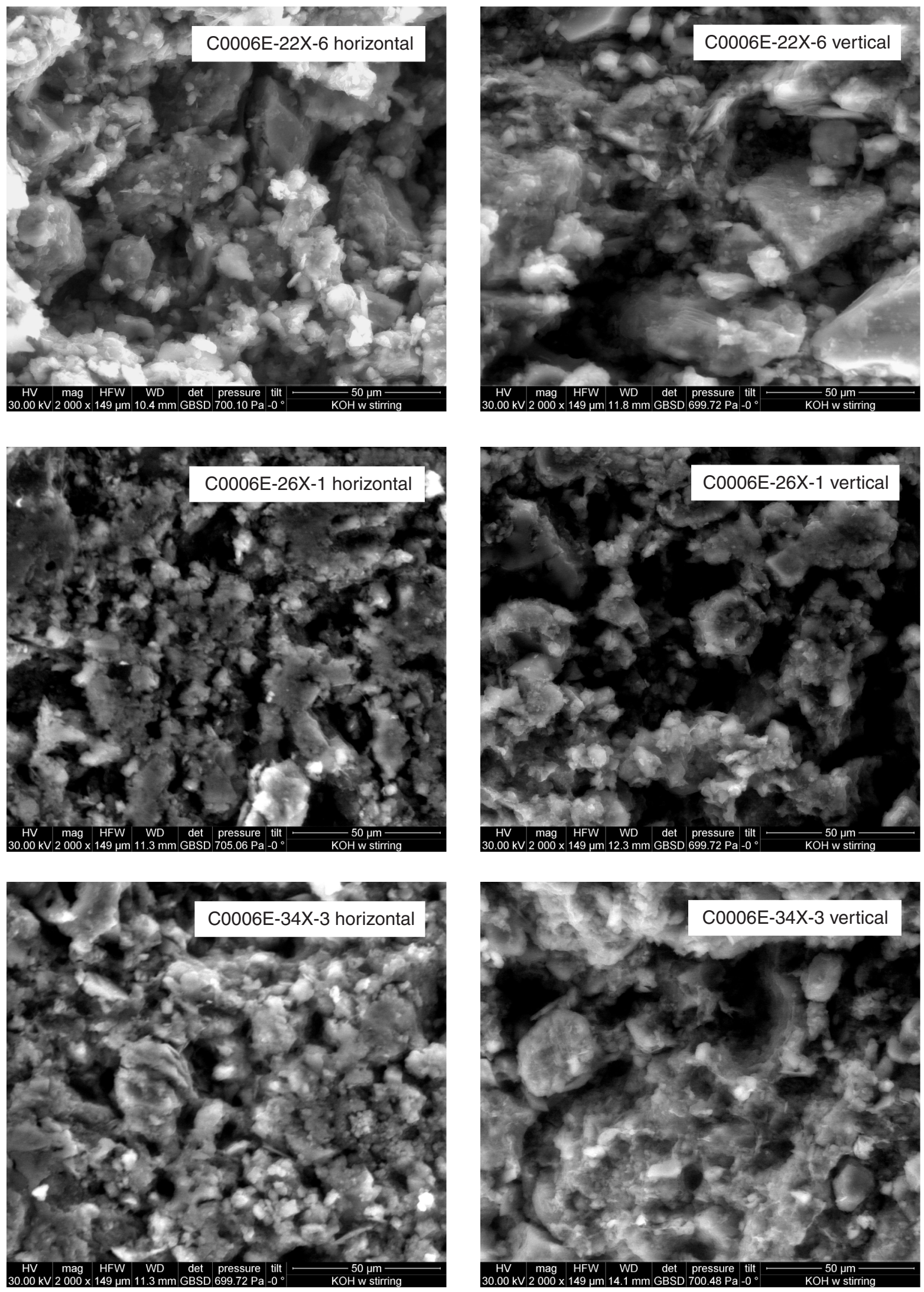
Figure F8 (continued).
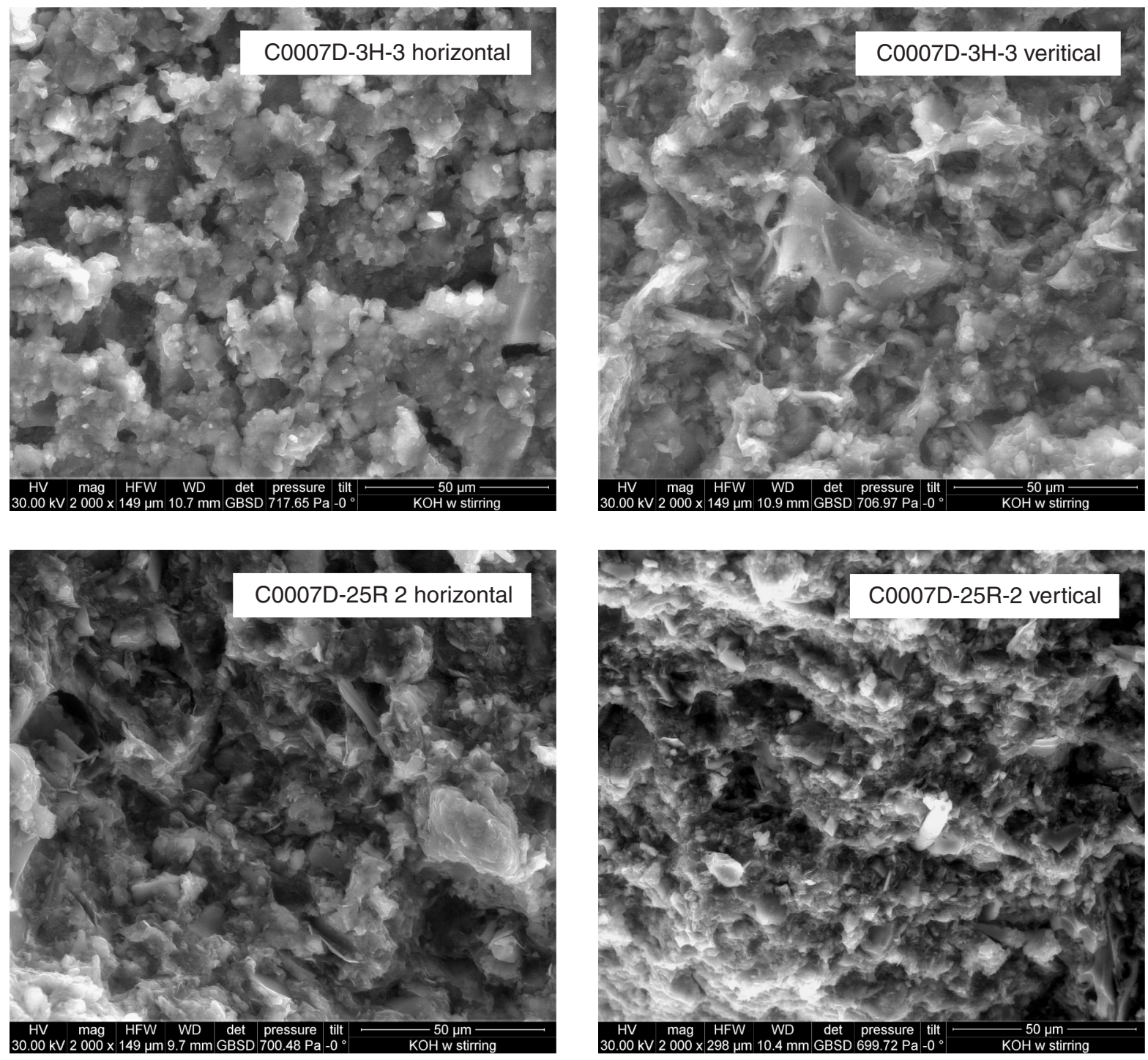
Figure F9. Rose diagrams showing orientation of particles (apparent long axis) on horizontal and vertical sections of samples from Sites C0002, C0006, and C0007. $d=$ standard deviation of particle orientation $\left({ }^{\circ}\right)$ and $i=$ index of orientation. (Continued on next page.)

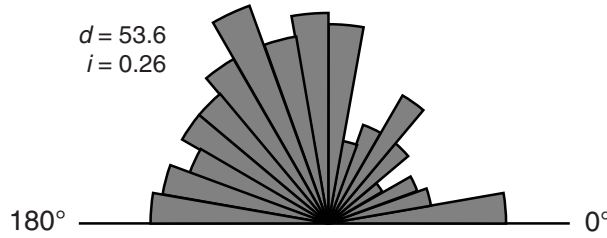

C0002B-10R-3, 8 horizontal section
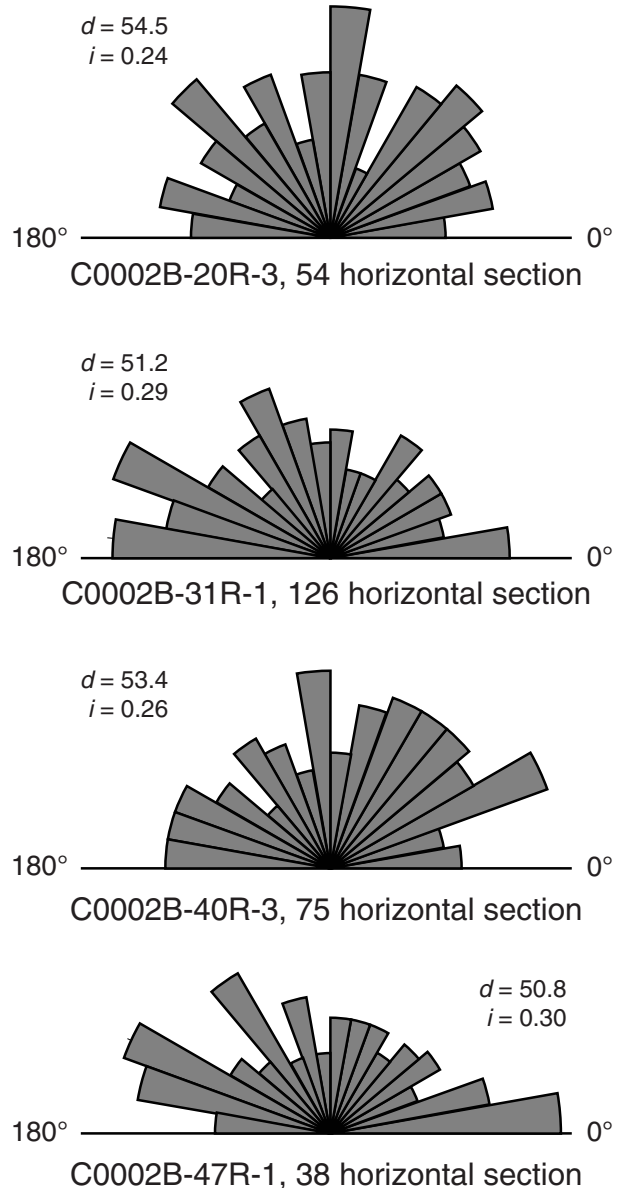

C0002B-47R-1, 38 horizontal section

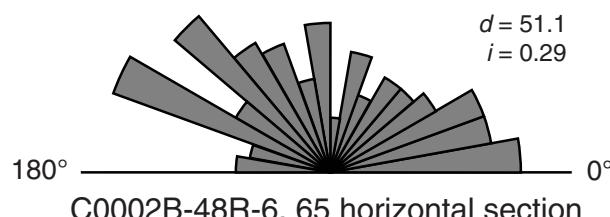

C0002B-48R-6, 65 horizontal section

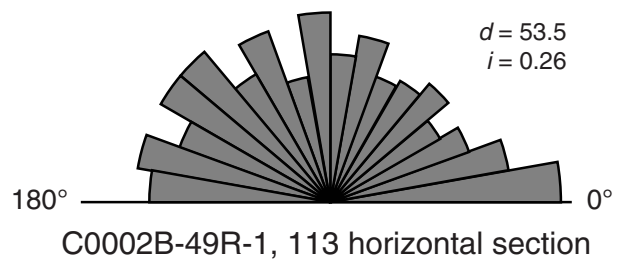

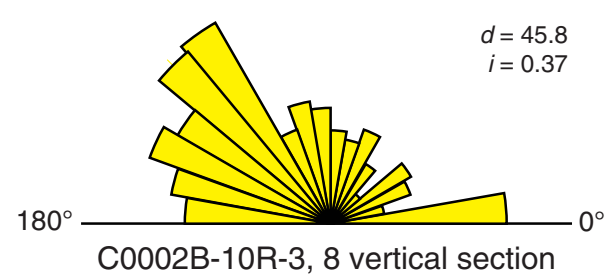
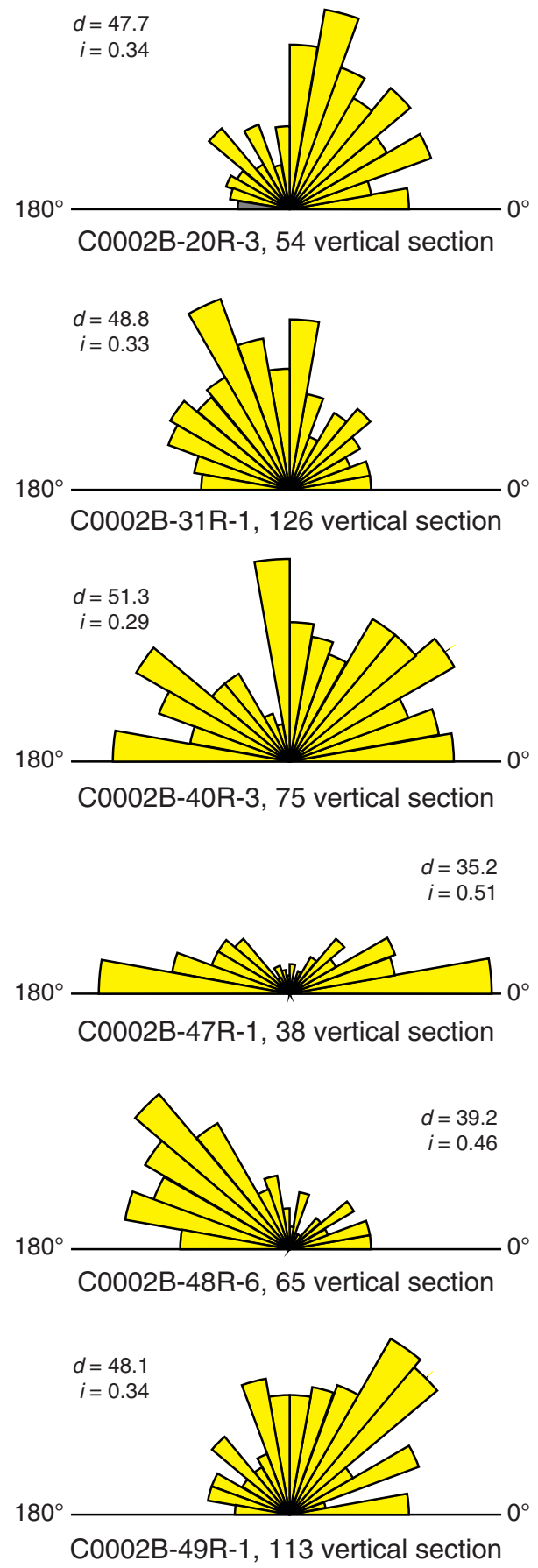
Figure F9 (continued).

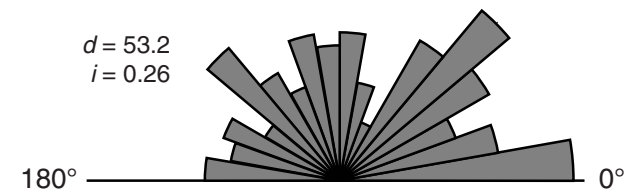

C0006E-5H-1, 126 horizontal section
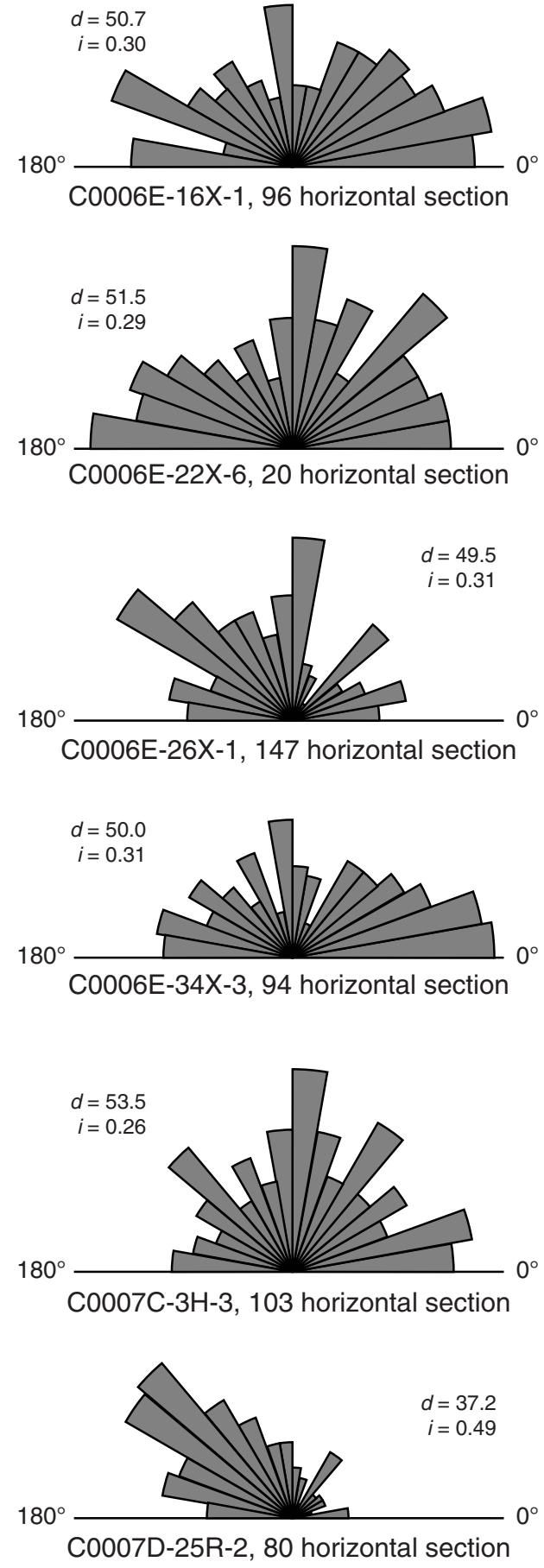

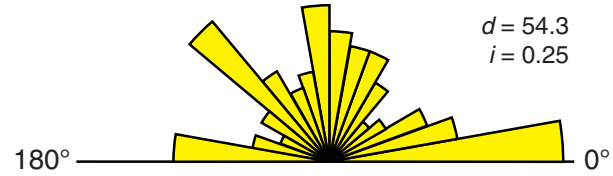

C0006E-5H-1, 126 vertical section

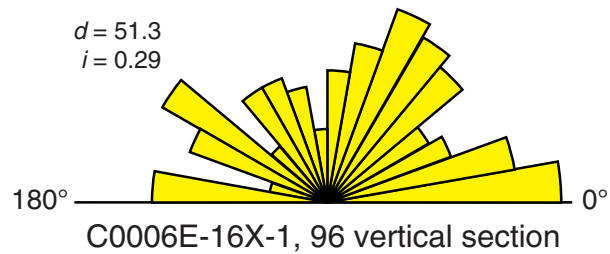

$d=43.9$

$i=0.39$
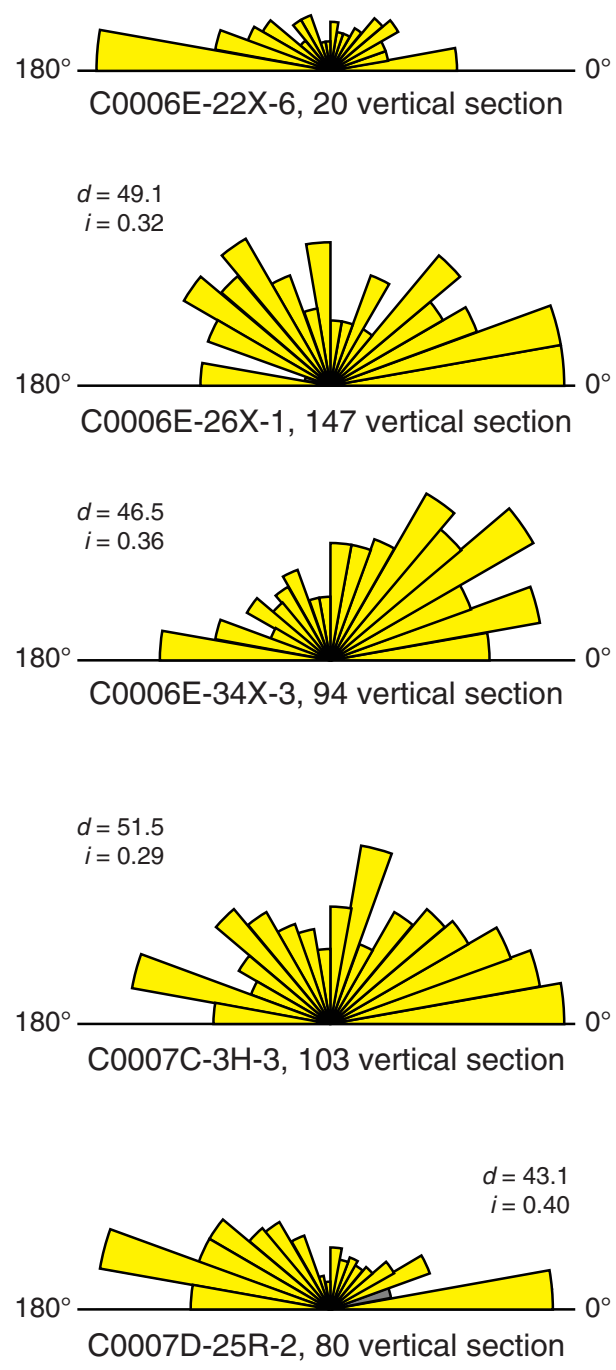
Figure F10. Cumulative frequency curves showing orientation of particles (apparent long axis) on horizontal and vertical sections of samples from Sites C0002, C0006, and C0007. The number of values in each bin $\left(10^{\circ}\right)$ was summed and normalized to $100 \%$.
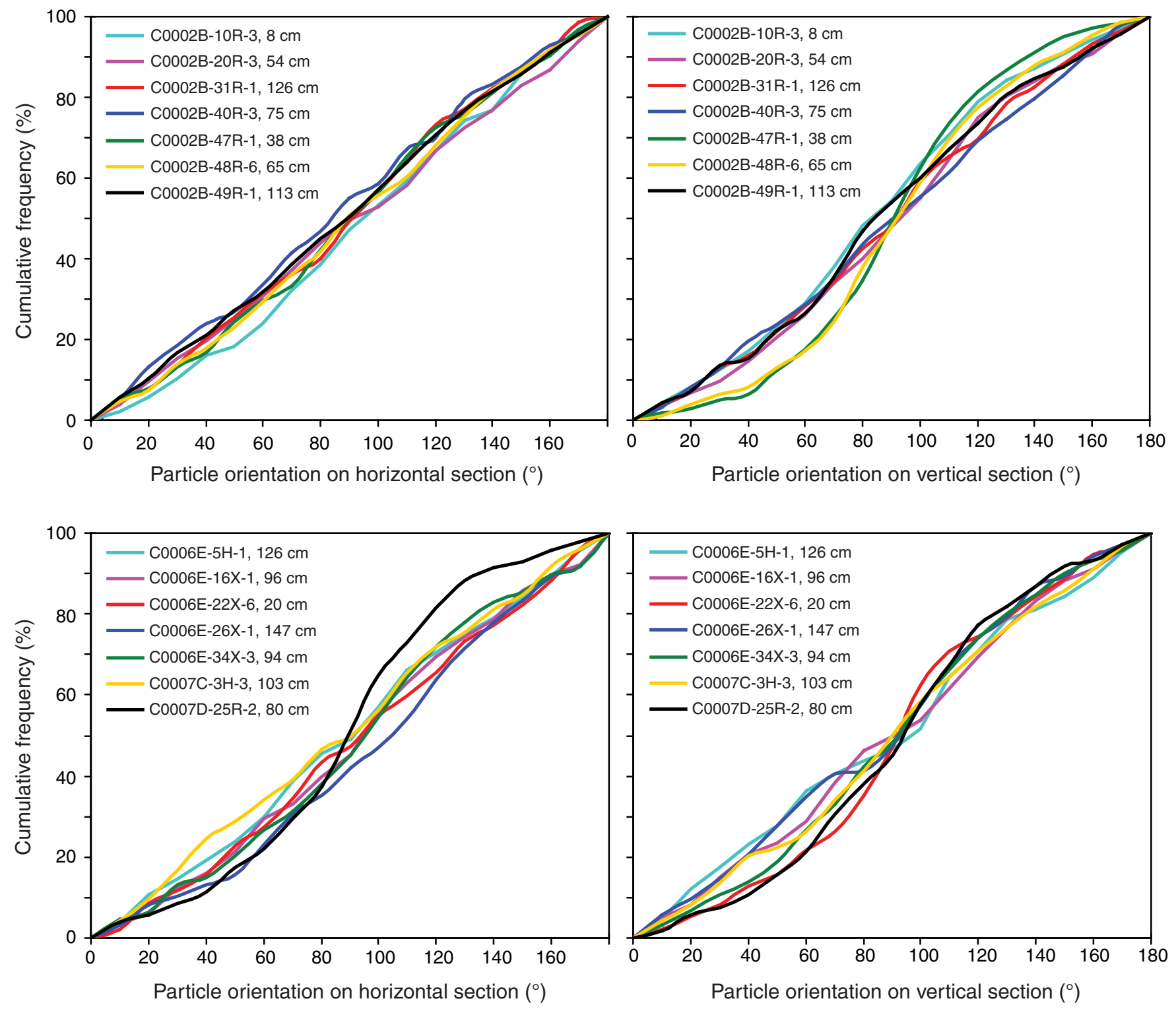
Figure F11. Index of orientation for vertical sections of mudstone samples from Sites C0002, C0006, and C0007 plotted against the corresponding value of compression index and test-derived value of $P^{\prime}{ }_{c}$.
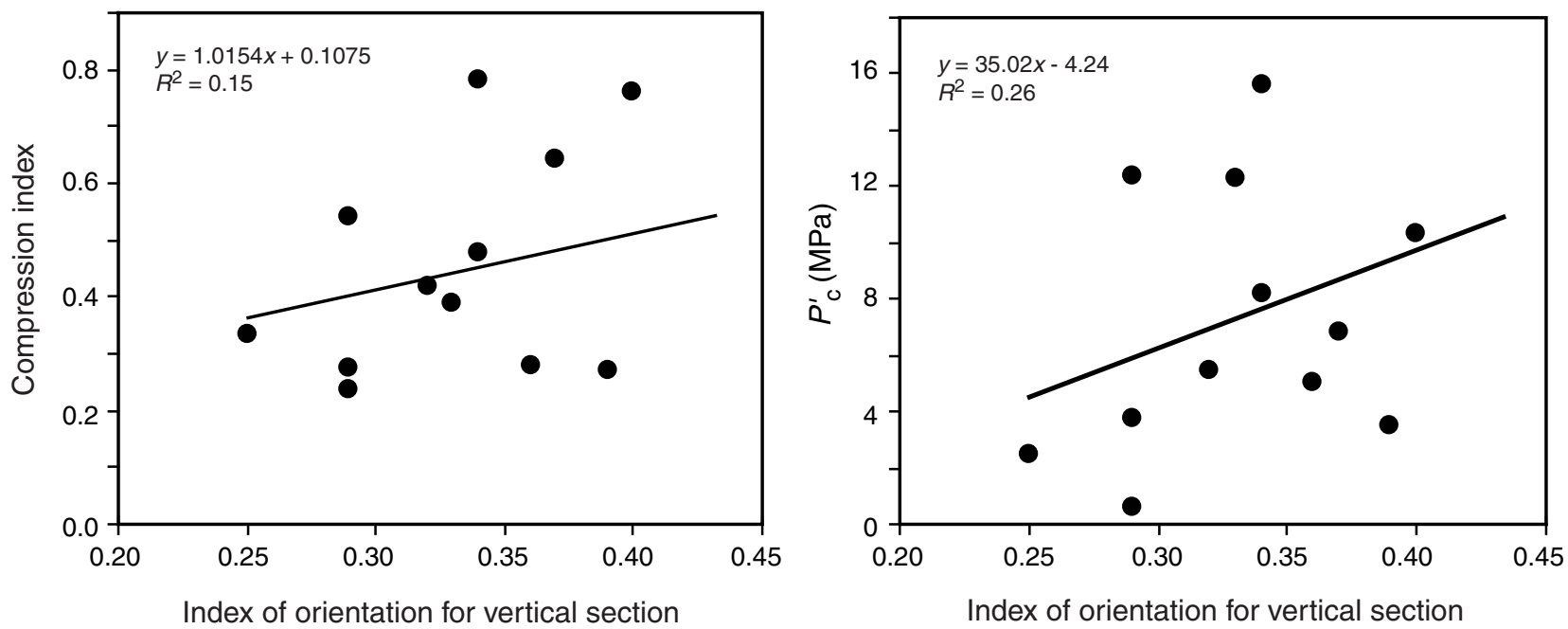
Table T1. Nomenclature and symbols used in this chapter.

\begin{tabular}{|c|c|c|c|}
\hline Symbol & Definition & Dimensions & SI units \\
\hline$H$ & Height of specimen & $\mathrm{L}$ & $\mathrm{mm}$ \\
\hline 0 & Initial height of specimen & $\mathrm{L}$ & $\mathrm{mm}$ \\
\hline$k$ & Hydraulic conductivity & $\mathrm{L} / \mathrm{T}$ & $\mathrm{m} / \mathrm{s}$ \\
\hline i & In situ hydraulic conductivity & $\mathrm{L} / \mathrm{T}$ & $\mathrm{m} / \mathrm{s}$ \\
\hline OCR & Over consolidation ratio & Dimensionless & - \\
\hline$P_{c}^{\prime}$ & Maximum pretest consolidation stress & $\mathrm{M} / \mathrm{LT}^{2}$ & $\mathrm{kPa}$ \\
\hline SED & Strain energy density & $\mathrm{M} / \mathrm{LT}^{2}$ & $\mathrm{~kJ} / \mathrm{m}^{3}$ \\
\hline$C_{v}$ & Coefficient of consolidation & $L^{2} / T$ & $\mathrm{~m}^{2} / \mathrm{s}$ \\
\hline$\eta$ & Porosity & Dimensionless & - \\
\hline e & Void ratio & Dimensionless & - \\
\hline$e_{i}$ & Initial void ratio measured on specimen & Dimensionless & - \\
\hline$e_{n}$ & In situ void ratio & Dimensionless & - \\
\hline$k$ & Intrinsic permeability & $\mathrm{L}^{2}$ & $\mathrm{~m}^{2}$ \\
\hline$k_{\mathrm{i}}$ & In situ intrinsic permeability & $\mathrm{L}^{2}$ & $\mathrm{~m}^{2}$ \\
\hline$m$ & & & $1 / \mathrm{kPa}$ \\
\hline$u$ & Basal pore pressure & $\mathrm{M} / \mathrm{LT}^{2}$ & $\mathrm{kPa}$ \\
\hline $\mathrm{b}$ & Back pressure & $\mathrm{M} / \mathrm{LT}^{2}$ & $\mathrm{kPa}$ \\
\hline$\Delta$ & Excess pore pressure & $\mathrm{M} / \mathrm{LT}^{2}$ & $\mathrm{kPa}$ \\
\hline$\Delta / \sigma_{v}$ & Normalized excess pore pressure & Dimensionless & - \\
\hline$\varepsilon$ & Axial strain & Dimensionless & $\%$ \\
\hline$\gamma_{w}$ & Unit weight of water & $\mathrm{M} / \mathrm{LT}^{2}$ & $\mathrm{kPa}$ \\
\hline$\sigma_{v}$ & Applied vertical stress & $\mathrm{M} / \mathrm{LT}^{2}$ & $\mathrm{kPa}$ \\
\hline$\sigma_{v}^{\prime}$ & Vertical effective stress & $\mathrm{M} / \mathrm{LT}^{2}$ & $\mathrm{kPa}$ \\
\hline$\sigma_{\mathrm{iv}}^{\prime}$ & Vertical effective stress prior to compression & $\mathrm{M} / \mathrm{LT}^{2}$ & $\mathrm{kPa}$ \\
\hline$\sigma_{\mathrm{vh}}^{\prime \prime}$ & Hydrostatic vertical effective stress & $\mathrm{M} / \mathrm{LT}^{2}$ & $\mathrm{kPa}$ \\
\hline$v$ & Dynamic fluid viscosity & $M / L T$ & Pa-s \\
\hline g & Gravitational acceleration & $\mathrm{M} / \mathrm{T}^{2}$ & $\mathrm{~m} / \mathrm{s}^{2}$ \\
\hline$\delta_{\mathrm{n}}$ & Axial displacement & $\mathrm{L}$ & $\mathrm{mm}$ \\
\hline$i$ & Index of orientation & Dimensionless & - \\
\hline$d$ & & & 0 \\
\hline
\end{tabular}

$-=$ not applicable 
Table T2. CRSC test conditions, specimen properties, and results for samples from Sites C0002, C0006, and C0007.

\begin{tabular}{|c|c|c|c|c|c|c|c|c|c|c|c|c|c|c|c|c|c|}
\hline $\begin{array}{c}\text { Test } \\
\text { specimen }\end{array}$ & $\begin{array}{l}\text { Hole, core, section, } \\
\text { interval }(\mathrm{cm})\end{array}$ & $\begin{array}{l}\text { Depth } \\
\text { (m CSF) }\end{array}$ & $\begin{array}{c}\text { Strain } \\
\text { rate } \\
(\% / \mathrm{h})\end{array}$ & $\begin{array}{c}u_{\mathrm{b}} \\
(\mathrm{kPa})\end{array}$ & $\underset{\text { (initial)* }}{\mathrm{e}}$ & $\underset{\text { (initial) }^{\dagger}}{\mathrm{e}}$ & $\begin{array}{c}H_{0} \\
(\mathrm{~mm})\end{array}$ & $\begin{array}{l}\text { Diameter } \\
(\mathrm{mm})\end{array}$ & $C_{c}$ & $C_{v}$ & $\begin{array}{c}P_{c}^{\prime} \\
\text { Casagrande } \\
(\mathrm{kPa})\end{array}$ & $\begin{array}{l}P_{c}^{\prime} \text { SED } \\
(\mathrm{kPa})\end{array}$ & $\begin{array}{l}P_{\mathrm{vh}}^{\prime} \\
(\mathrm{kPa})\end{array}$ & $\begin{array}{c}\text { OCR } \\
\text { Casagrande }\end{array}$ & OCR SED & $k\left(\mathrm{~m}^{2}\right)^{\ddagger}$ & $k\left(m^{2}\right)^{\star *}$ \\
\hline \multicolumn{18}{|c|}{$315-$} \\
\hline MU-12 & C0002B-10R-3, 8 & 553.80 & 0.50 & 410 & 0.75 & 0.74 & 16.50 & 41.4 & 0.642 & $3.91 \mathrm{E}-08$ & 6,664 & 6,818 & 4,041 & 1.65 & 1.69 & $3.83 \mathrm{E}-18$ & 6.07E-18 \\
\hline MU-13 & C0002B-20R-3, 54 & 650.37 & 0.50 & 413 & 0.66 & 0.68 & 22.00 & 41.4 & 0.477 & $6.94 \mathrm{E}-07$ & 7,949 & 8,224 & 4,853 & 1.64 & 1.69 & $2.07 \mathrm{E}-17$ & $2.66 \mathrm{E}-17$ \\
\hline MU-14 & C0002B-31R-1, 126 & 752.26 & 0.50 & 414 & 0.63 & 0.62 & 25.40 & 41.4 & 0.390 & $3.96 \mathrm{E}-07$ & 11,959 & 12,310 & 5,831 & 2.05 & 2.11 & $1.24 \mathrm{E}-17$ & $2.25 \mathrm{E}-17$ \\
\hline MU-15 & C0002B-40R-3, 75 & 836.58 & 0.50 & 414 & 0.74 & 0.65 & 24.10 & 41.4 & 0.540 & $3.28 \mathrm{E}-07$ & 12,029 & 12,402 & 6,648 & 1.81 & 1.87 & $10.00 \mathrm{E}-18$ & $1.24 \mathrm{E}-17$ \\
\hline MU-16 & C0002B-47R-1, 38 & 900.88 & 0.50 & 414 & 0.68 & 0.67 & 23.00 & 41.4 & 0.519 & $6.96 \mathrm{E}-08$ & 13,019 & 12,928 & 7,260 & 1.79 & 1.78 & $2.67 \mathrm{E}-17$ & $2.85 \mathrm{E}-17$ \\
\hline MU-17 & C0002B-48R-6, 65 & 916.31 & 0.50 & 413 & 0.76 & 0.74 & 25.30 & 41.4 & 0.600 & $4.24 \mathrm{E}-08$ & 14,475 & 14,222 & 7,404 & 1.95 & 1.92 & $5.76 \mathrm{E}-18$ & $5.72 \mathrm{E}-18$ \\
\hline MU-18 & C0002B-49R-1, 113 & 920.63 & 0.50 & 414 & 0.71 & 0.72 & 22.40 & 41.4 & 0.780 & $1.38 \mathrm{E}-07$ & 14,055 & 15,604 & 7,444 & 1.89 & 2.10 & $5.15 \mathrm{E}-18$ & $8.84 \mathrm{E}-18$ \\
\hline PSU-90 & C0002B-17R-4, 8 & 622.99 & 0.23 & 300 & 1.16 & 0.95 & 20.02 & 36.6 & NA & $9.76 \mathrm{E}-07$ & NA & NA & 5,562 & NA & NA & $1.03 \mathrm{E}-17$ & $1.45 \mathrm{E}-17$ \\
\hline PSU-96 & C0002B-28R-2, 8 & 724.24 & 0.23 & 300 & 0.61 & 0.66 & 20.06 & 36.6 & 0.483 & NA & 12,540 & 13,200 & 5,547 & 2.26 & 2.38 & NA & NA \\
\hline PSU-102 & C0002B-28R-2, 8 & 724.24 & 0.23 & 300 & 0.53 & 0.66 & 20.04 & 36.6 & 0.462 & $1.22 \mathrm{E}-07$ & 12,492 & 14,437 & 5,547 & 2.25 & 2.60 & $2.56 \mathrm{E}-18$ & $4.42 \mathrm{E}-18$ \\
\hline PSU-105 & C0002B-41R-4, 8 & 846.83 & 0.23 & 300 & 0.80 & 0.68 & 21.07 & 36.6 & 0.589 & $1.88 \mathrm{E}-07$ & 14,603 & 15,886 & 6,746 & 2.16 & 2.35 & $4.98 \mathrm{E}-18$ & $6.41 \mathrm{E}-18$ \\
\hline \multicolumn{18}{|c|}{$316-$} \\
\hline MU-19 & C0006E-5H-1, 128 & 35.56 & 0.50 & 201 & 0.89 & 0.92 & 24.40 & 41.4 & 0.335 & 2.67E-06 & 2,610 & 2,448 & 285 & 9.14 & 8.58 & $1.85 \mathrm{E}-16$ & $6.20 \mathrm{E}-16$ \\
\hline MU-20 & C0006E-16X-1, 113 & 89.96 & 0.50 & 202 & 0.70 & 0.83 & 24.40 & 41.4 & 0.273 & $4.66 \mathrm{E}-06$ & 3,329 & 3,719 & 756 & 4.41 & 4.92 & $1.02 \mathrm{E}-16$ & $3.15 \mathrm{E}-16$ \\
\hline MU-21 & C0006E-22X-6, 5 & 150.04 & 0.50 & 201 & 0.82 & 0.66 & 24.40 & 41.4 & 0.271 & $1.57 \mathrm{E}-07$ & 3,261 & 3,518 & 1,301 & 2.51 & 2.71 & $6.08 \mathrm{E}-18$ & $1.71 \mathrm{E}-17$ \\
\hline MU-22 & C0006E-26X-1, 126 & 183.50 & 0.50 & 204 & 0.87 & 0.62 & 24.40 & 41.4 & 0.418 & $1.38 \mathrm{E}-07$ & 5,404 & 5,431 & 1,625 & 3.33 & 3.34 & $5.01 \mathrm{E}-18$ & $1.44 \mathrm{E}-17$ \\
\hline MU-23 & C0006E-34X-3, 59 & 261.64 & 0.50 & 205 & 0.68 & 0.65 & 24.40 & 41.4 & 0.278 & $1.33 \mathrm{E}-07$ & 4,938 & 5,067 & 2,387 & 2.07 & 2.12 & $2.46 \mathrm{E}-18$ & 4.47E-18 \\
\hline MU-24 & C0007C-3H-3, 104 & 32.64 & 0.50 & 202 & 0.88 & 0.86 & 24.38 & 41.4 & 0.236 & $1.10 \mathrm{E}-07$ & 534 & 573 & 264 & 2.02 & 2.17 & $5.61 \mathrm{E}-17$ & 6.97E-17 \\
\hline MU-25 & C0007D-25R-2, 66 & 400.59 & 0.50 & 205 & 0.96 & 0.94 & 24.40 & 41.4 & 0.761 & $4.86 \mathrm{E}-08$ & 10,447 & 10,321 & 3,812 & 2.74 & 2.71 & $4.42 \mathrm{E}-18$ & $7.02 \mathrm{E}-18$ \\
\hline
\end{tabular}

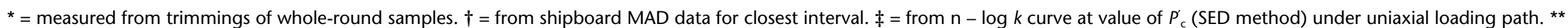
$=$ from $n-\log k$ curve at value of in situ vertical hydrostatic effective stress. $C_{c}$ and $C_{v}$ are based on uniaxial stress path, which may differ from actual loading path. NA $=$ not applicable. 
Table T3. Quantification of sample disturbance for CRSC test specimens. Ratings criteria are from Lunne et al. (1997).

\begin{tabular}{|c|c|c|c|c|c|c|c|}
\hline Specimen & $\begin{array}{l}\text { Hole, core, section, } \\
\text { interval }(\mathrm{cm})\end{array}$ & $\begin{array}{l}\text { Depth } \\
\text { (m CSF) }\end{array}$ & $\begin{array}{l}\text { OCR } \\
\text { SED }\end{array}$ & $e_{\mathrm{i}}$ & $e_{\mathrm{n}}$ & $\Delta e / e_{\mathrm{i}}$ & Rating \\
\hline & $315-$ & & & & & & \\
\hline MU-12 & C0002B-10R-3, 8 & 553.80 & 1.69 & 0.75 & 0.49 & 0.35 & Very poor \\
\hline MU-13 & C0002B-20R-3, 54 & 650.37 & 1.69 & 0.66 & 0.51 & 0.22 & Very poor \\
\hline MU-14 & C0002B-31R-1, 126 & 752.26 & 2.11 & 0.63 & 0.54 & 0.13 & Poor \\
\hline MU-15 & C0002B-40R-3, 75 & 836.58 & 1.87 & 0.74 & 0.60 & 0.18 & Very poor \\
\hline MU-16 & C0002B-47R-1, 38 & 900.88 & 1.78 & 0.68 & 0.61 & 0.11 & Poor \\
\hline MU-17 & C0002B-48R-6, 65 & 916.31 & 1.92 & 0.76 & 0.69 & 0.09 & Poor \\
\hline MU-18 & C0002B-49R-1, 113 & 920.63 & 2.10 & 0.71 & 0.58 & 0.19 & Very poor \\
\hline PSU-90 & C0002B-17R-4, 8 & 622.99 & NA & 1.16 & 0.74 & 0.36 & Very poor \\
\hline PSU-96 & C0002B-28R-2, 8 & 724.24 & 2.38 & 0.61 & 0.42 & 0.31 & Very poor \\
\hline PSU-102 & C0002B-28R-2, 8 & 724.24 & 2.60 & 0.53 & 0.40 & 0.23 & Very poor \\
\hline \multirow[t]{2}{*}{ PSU-105 } & C0002B-41R-4, 8 & 846.83 & 2.35 & 0.80 & 0.64 & 0.20 & Very poor \\
\hline & $316-$ & & & & & & \\
\hline MU-19 & C0006E-5H-1, 128 & 35.56 & 8.58 & 0.89 & 0.57 & 0.37 & Very poor \\
\hline MU-20 & C0006E-16X-1, 113 & 89.96 & 4.92 & 0.70 & 0.31 & 0.56 & Very poor \\
\hline MU-21 & C0006E-22X-6, 5 & 150.04 & 2.71 & 0.82 & 0.44 & 0.47 & Very poor \\
\hline MU-22 & C0006E-26X-1, 126 & 183.50 & 3.34 & 0.87 & 0.52 & 0.40 & Very poor \\
\hline MU-23 & C0006E-34X-3, 59 & 261.64 & 2.12 & 0.68 & 0.38 & 0.44 & Very poor \\
\hline MU-24 & C0007C-3H-3, 104 & 32.64 & 2.17 & 0.88 & 0.74 & 0.16 & Very poor \\
\hline MU-25 & C0007D-25R-2, 66 & 400.59 & 2.71 & 0.96 & 0.81 & 0.15 & Very poor \\
\hline
\end{tabular}

$e_{\mathrm{n}}=$ value at intersection point of $P_{\mathrm{c}}^{\prime}$ using SED method. NA $=$ not applicable.

Table T4. Values of in situ permeant properties, void ratio, and in situ hydraulic conductivity for sample depths at Sites C0002, C0006, and C0007.

\begin{tabular}{|c|c|c|c|c|c|c|c|c|c|}
\hline \multirow{3}{*}{$\begin{array}{c}\text { Test } \\
\text { specimen }\end{array}$} & \multirow{3}{*}{$\begin{array}{l}\text { Hole, core, section, } \\
\text { interval }(\mathrm{cm})\end{array}$} & \multirow{3}{*}{$\begin{array}{l}\text { Depth } \\
\text { (m CSF) }\end{array}$} & \multirow{3}{*}{$\begin{array}{c}\text { Temperature } \\
\left({ }^{\circ} \mathrm{C}\right)\end{array}$} & \multicolumn{2}{|c|}{ In situ fluid properties } & \multirow{2}{*}{\multicolumn{2}{|c|}{ In situ values at $P_{c}^{\prime}$}} & \multirow{2}{*}{\multicolumn{2}{|c|}{ In situ values at $\sigma_{v h}^{\prime}$}} \\
\hline & & & & \multirow{2}{*}{$\begin{array}{l}\text { Density } \\
\left(\mathrm{kg} / \mathrm{m}^{3}\right)\end{array}$} & \multirow{2}{*}{$\begin{array}{l}\text { Viscosity } \\
\left(10^{-3} \mathrm{~Pa} \cdot \mathrm{s}\right)\end{array}$} & & & & \\
\hline & & & & & & $e^{*}$ & $K(\mathrm{~m} / \mathrm{s})$ & $e^{\dagger}$ & $K(\mathrm{~m} / \mathrm{s})$ \\
\hline & $315-$ & & & & & & & & \\
\hline MU-12 & C0002B-10R-3, 8 & 553.80 & 24.2 & 1026 & 0.95 & 0.49 & $4.06 \mathrm{E}-11$ & 0.53 & $6.43 \mathrm{E}-11$ \\
\hline MU-13 & C0002B-20R-3, 54 & 650.37 & 28.1 & 1025 & 0.87 & 0.51 & $2.38 \mathrm{E}-10$ & 0.53 & $3.06 \mathrm{E}-10$ \\
\hline MU-14 & C0002B-31R-1, 126 & 752.26 & 32.1 & 1024 & 0.81 & 0.54 & $1.54 \mathrm{E}-10$ & 0.57 & $2.80 \mathrm{E}-10$ \\
\hline MU-15 & C0002B-40R-3, 75 & 836.58 & 35.5 & 1023 & 0.75 & 0.60 & $1.33 \mathrm{E}-10$ & 0.63 & $1.66 \mathrm{E}-10$ \\
\hline MU-16 & C0002B-47R-1, 38 & 900.88 & 38.1 & 1023 & 0.72 & 0.61 & $3.72 \mathrm{E}-10$ & 0.61 & $3.98 \mathrm{E}-10$ \\
\hline MU-17 & C0002B-48R-6, 65 & 916.31 & 38.7 & 1022 & 0.71 & 0.69 & $8.14 \mathrm{E}-11$ & 0.69 & 8.08E-11 \\
\hline MU-18 & C0002B-49R-1, 113 & 920.63 & 38.9 & 1022 & 0.71 & 0.58 & $7.30 \mathrm{E}-11$ & 0.63 & $1.25 \mathrm{E}-10$ \\
\hline PSU-90 & C0002B-17R-4, 8 & 622.99 & 27.0 & 1025 & 0.90 & 0.74 & $1.16 \mathrm{E}-10$ & 0.78 & $1.63 \mathrm{E}-10$ \\
\hline PSU-96 & C0002B-28R-2, 8 & 724.24 & 31.0 & 1024 & 0.82 & 0.42 & NA & 0.46 & NA \\
\hline PSU-102 & C0002B-28R-2, 8 & 724.24 & 31.0 & 1024 & 0.82 & 0.40 & $3.13 \mathrm{E}-11$ & 0.46 & $5.40 \mathrm{E}-11$ \\
\hline \multirow[t]{2}{*}{ PSU-105 } & C0002B-41R-4, 8 & 846.83 & 35.9 & 1023 & 0.75 & 0.64 & $6.69 \mathrm{E}-11$ & 0.67 & $8.61 \mathrm{E}-11$ \\
\hline & 316- & & & & & & & & \\
\hline MU-19 & C0006E-5H-1, 128 & 35.56 & 2.6 & 1028 & 1.65 & 0.57 & $1.13 \mathrm{E}-09$ & 0.74 & $3.79 \mathrm{E}-09$ \\
\hline MU-20 & C0006E-16X-1, 113 & 89.96 & 4.1 & 1028 & 1.58 & 0.31 & $6.48 \mathrm{E}-10$ & 0.43 & $2.01 \mathrm{E}-09$ \\
\hline MU-21 & C0006E-22X-6, 5 & 150.04 & 5.7 & 1028 & 1.51 & 0.44 & 4.07E-11 & 0.52 & $1.15 \mathrm{E}-10$ \\
\hline MU-22 & C0006E-26X-1, 126 & 183.50 & 6.6 & 1028 & 1.47 & 0.52 & $3.44 \mathrm{E}-11$ & 0.65 & $9.88 \mathrm{E}-11$ \\
\hline MU-23 & C0006E-34X-3, 59 & 261.64 & 8.7 & 1028 & 1.39 & 0.38 & $1.79 \mathrm{E}-11$ & 0.44 & $3.25 \mathrm{E}-11$ \\
\hline MU-24 & C0007C-3H-3, 104 & 32.64 & 2.5 & 1028 & 1.65 & 0.74 & $3.42 \mathrm{E}-10$ & 0.78 & $4.25 \mathrm{E}-10$ \\
\hline MU-25 & C0007D-25R-2, 66 & 400.59 & 12.5 & 1028 & 1.26 & 0.81 & $3.55 \mathrm{E}-11$ & 0.88 & $5.64 \mathrm{E}-11$ \\
\hline
\end{tabular}

${ }^{*}=$ value at intersection of $P_{c}^{\prime}$ (SED method) under uniaxial loading path. $\dagger=$ value at intersection of in situ vertical hydrostatic effective stress. $K$ is computed from values of intrinsic permeability, in situ fluid density, and in situ fluid viscosity. NA = not applicable. 
Table T5. Results of statistical analysis of microfabric on horizontal and vertical sections of mudstone using environmental SEM images. Specimens are from intervals immediately adjacent to CRSC test specimens, Sites C0002, C0006, and C0007.

\begin{tabular}{|c|c|c|c|c|c|c|c|}
\hline \multirow[b]{2}{*}{$\begin{array}{l}\text { Hole, core, section, } \\
\text { interval }(\mathrm{cm})\end{array}$} & \multirow[b]{2}{*}{$\begin{array}{l}\text { Depth } \\
\text { (m CSF) }\end{array}$} & \multicolumn{3}{|c|}{ Horizontal section } & \multicolumn{3}{|c|}{ Vertical section } \\
\hline & & $\begin{array}{l}\text { Grains } \\
\text { counted }\end{array}$ & $\begin{array}{c}\text { Standard } \\
\text { deviation } \\
\left({ }^{\circ}\right)\end{array}$ & $\begin{array}{l}\text { Index of } \\
\text { orientation }\end{array}$ & $\begin{array}{l}\text { Grains } \\
\text { counted }\end{array}$ & $\begin{array}{c}\text { Standard } \\
\text { deviation } \\
\left({ }^{\circ}\right)\end{array}$ & $\begin{array}{l}\text { Index of } \\
\text { orientation }\end{array}$ \\
\hline \multicolumn{8}{|l|}{$315-$} \\
\hline C0002B-10R-3, 8 & 553.80 & 260 & 53.6 & 0.26 & 294 & 45.8 & 0.37 \\
\hline C0002B-20R-3, 54 & 650.37 & 338 & 54.5 & 0.24 & 251 & 47.7 & 0.34 \\
\hline C0002B-31R-1, 126 & 752.26 & 197 & 51.2 & 0.29 & 248 & 48.8 & 0.33 \\
\hline C0002B-40R-3, 75 & 836.58 & 167 & 53.4 & 0.26 & 192 & 51.3 & 0.29 \\
\hline C0002B-47R-1, 38 & 900.88 & 207 & 50.8 & 0.30 & 217 & 35.2 & 0.51 \\
\hline C0002B-48R-6, 65 & 916.31 & 174 & 51.1 & 0.29 & 268 & 39.2 & 0.46 \\
\hline C0002B-49R-1, 113 & 920.63 & 429 & 53.5 & 0.26 & 207 & 48.1 & 0.34 \\
\hline \multicolumn{8}{|l|}{$316-$} \\
\hline C0006E-5H-1, 126 & 35.54 & 204 & 53.2 & 0.26 & 155 & 54.3 & 0.25 \\
\hline C0006E-16X-1, 96 & 88.99 & 233 & 50.7 & 0.30 & 180 & 51.3 & 0.29 \\
\hline C0006E-22X-6, 20 & 150.19 & 179 & 51.5 & 0.29 & 133 & 43.9 & 0.39 \\
\hline C0006E-26X-1, 147 & 183.71 & 196 & 49.5 & 0.31 & 180 & 49.1 & 0.32 \\
\hline C0006E-34X-3, 94 & 261.99 & 221 & 50.0 & 0.31 & 217 & 46.5 & 0.36 \\
\hline C0007C-3H-3, 103 & 32.63 & 228 & 53.5 & 0.26 & 237 & 51.5 & 0.29 \\
\hline C0007D-25R-2, 80 & 400.73 & 294 & 37.2 & 0.49 & 311 & 43.1 & 0.40 \\
\hline
\end{tabular}

